\title{
Yönetsel Sürecin Bir Fonksiyonu Olarak Kurumsal Sosyal Sorumluluk
}

\author{
Mustafa Kemal ÖKTEM* \\ Ŭur SADİOĞLU** \\ Nafiz TURGUT ${ }^{* *}$
}

\section{Öz}

Kurumsal sosyal sorumluluk (KSS) uygulamaları özellikle iş dünyasındaki örgütlerin belirli bir yasalkurumsal çevrenin kodlarına uygun olarak, daha çok gönüllülük esasına dayalı olarak gerçekleşmektedir. Gelişmişinden gelişmekte olan ülkeler grubuna farklı düzeylerde KSS anlayışı, algısı ve amacı görmek mümkündür. Ancak, küreselleşme ve bölgeselleşme sürecinde piyasa ekonomisinin temel belirleyici alan olduğu mal ve hizmet üretim süreçlerinde KSS konusunda genel kabul gören ilkeler, yaklaşımlar, projeler ve örgütlenmeler ortaya çıkmıştır. Birleşmiş Milletler, Avrupa Birliği, Avrupa Konseyi, Dünya Bankası gibi uluslararası ya da ulusüstü kuruluşların KSS konusunda politika içerikleri ve standartları geliştirdikleri görülmektedir. Bununla birlikte Türkiye de bu kuruluşların önemli bir bölümünün üyesi ya da $A B$ örneğinde olduğu gibi adayı olduğu için benzer KSS politikaları karşısında kendi iç çevresinde önemli kurumsal, yasal, kültürel ve yönetsel dönüşümler geçirmektedir. Türkiye’nin önde gelen mal ve hizmet üreticilerinin kapsamlı ve güncel KSS politikaları bulunmaktadır. Kamu kurum ve kuruluşları da artan oranda ilgili politika alanında ortaya çıkan sözleşmeleri kabul etmekte ve kurumsal yapı, iş süreçleri ve personel yönetimlerini dönüştürmektedirler. BM Küresel İlkeler Sözleşmesi bu bağlamda öne çıkmakta ve Türkiye'deki kurumlar bu sözleşmeye üye olmaktadırlar. Bu çalışmada, Türkiye'den Sözleşmeye üye olan bir kamu kurumu (belediye) ve bir özel sektör kuruluşu ile üye olmayan bir kamu kurumu (belediye) ve bir özel sektör kuruluşu incelenerek sonuçlar çıkarılmaya çalışılmıştır. Türkiye'de KSS politikası ve ilkelerinin kurumlarda ne tür etkiler ortaya koyduğu ve nasıl bir dönüşümü hareketlendirdiği analiz edilmiştir.

Anahtar kelimeler: Kamu Yönetimi, Kurumsal Sosyal Sorumluluk, Türkiye, Uluslararası İlkeler, Yönetişim.

\section{Corporate Social Responsibility As a Function of Administrative Process}

\footnotetext{
Abstract

Activities under Corporate Social Responsibility (CSR) are mostly carried out on voluntary basis in accordance with legal-institutional framework of the organizations in particularly in business

* Prof.Dr., Hacettepe Üniversitesi Siyaset Bilimi ve Kamu Yönetimi Bölümü, kemalok@hacettepe.edu.tr

** Yrd.Doç.Dr., Hacettepe Üniversitesi Siyaset Bilimi ve Kamu Yönetimi Bölümü, ugursadi@hacettepe.edu.tr

*** Dr., Akfen Holding, nafizim@yahoo.co.uk
} 
world. It is possible to observe understandings, perceptions and purposes of CSR at different levels from developed countries to the developing ones. On the other hand, generally accepted principles, approaches, projects and organizations on CSR have emerged for production process of the goods and services in which market economy is the basic determinant area for globalization and regionalization. It is also seen that international or supranational organizations such as United Nations, European Union, Council of Europe developed policy contents and standards concerning CSR. Nevertheless, Turkey has witnessed major institutional, legal, cultural and administrative transformations within her own structure against similar CSR policies since she is already a member to most of these organizations or a candidate for them (such as EU). Leading goods and service producers of Turkey have comprehensive and updated CSR policies. Public institutions and organizations increasingly adopt the contracts developed in the related areas and transform their institutional structures, business processes and staff management. In this regard, Global Compact of UN come to the fore and institutions in Turkey started to participate it. In this study, a public institution (municipality) and a private sector organization which are participants to Global Compact with a public institution (municipality) and a private sector organization which are not participants have been examined with a purpose to reach conclusions. What kind of impacts CSR policies and principles have on the institutions and what kind of transformations they triggered have also been analysed.

Keywords: Public Administration, Corporate Social Responsibility, Turkey, International Principles, Governance.

\section{Giriş}

İnsani bir değer olan sorumluluk gerek bireysel ve gerekse toplumsal yaşamın en önemli unsurlarından birisidir. İnsanın doğumuyla başlayan sorumluluklar silsilesi, yaşamının her döneminde çeşitlenerek etkili olmakta; hatta insanın ölümünden sonra arkasında bıraktıkları da bireysel sorumluluğunun yanı sıra toplumsal sorumluluğunu devam yansıtmaktadır.

Sorumlulukla birlikte yapılan işlerin sonuçlarının üstlenilmesi ve hesap verme yükümlülügü söz konusu olduğuna göre, yaşamın bu ayrılmaz parçasının sosyal bir içerik taşıdığını söylemek mümkündür. Özellikle toplumsal yaşamdaki gelişmeler, önce sanayi ve sonrasında yaşanan bilgi devrimi, insanların toplum halinde yaşamalarından kaynaklanan çeşitli sorunlar, küreselleşme ve gittikçe azalan kaynakların verimli kullanılmasıyla ilgili arayışlar sonucunda sorumluluk kavramında yeni bir boyut ortaya çıkmıştır: "Sosyal Sorumluluk".

Küreselleşme süreci birçok konuyu öne çıkarmış ve toplumun çeşitli kesimlerinin bu konular etrafında etkili olmasını, bilgi paylaşımını, alış-verişi, iletişimi ve etkileşimi geometrik bir hıza kavuşturmuştur. Bu süreçte tüm sektörlerde örgütler ve yönetimler iç ve dış çevrelerine karşı daha açı ve duyarlı hale gelmişlerdir ya da dinamikler örgütleri bu yöne sevk etmiştir. Bu minvalde öne çıkan en önemli kavramlardan birisi Kurumsal Sosyal Sorumluluk (KSS) olmuştur. Kurumsal sosyal sorumluluk, geniş anlamıla mal veya hizmet üreten örgütlerin muhattapları olan toplumsal kesimlere karşı sadece bu maddi çıkar ilişkisiyle yaklaşmamasını; bunun 
ötesinde birlikte yaşama, paylaşma, koruma, değer katma, karar alma, destekleme gibi temeller üzerinden ilişkilerini yeniden yorumlamaları anlamına gelmektedir. Elbette yakın dönemdeki bilgi ve iletişim teknolojilerindeki hızlı gelişmeler, ülkeler arasındaki sınırların gevşemesi, büyük uluslararası kuruluşların rekabeti, ortaya çıkan toplumsal hassasiyetler, toplumsal düşünce çerçevesindeki ideolojik değişiklikler, hukuk nosyonunun toplum çıkarı ya da kamu yararı üzerinden güç kazanması ve bireylerin tercihlerinde sosyal, çevresel ve kültürel sonuçların belirleyici olması KSS’ye olan ilgiyi artırmıştır. Bir anlamda kurumların sürdürülebilirliği bu yaklaşımın sahiplenilmesine ve ilkelerine bağlılığa dayanmıştır. İşte bu çalışmada sırasıyla KSS kavramı analiz edilecek, KSS’nin tarihsel gelişimi özetlenecek, KSS yaklaşımları ve bu yaklaşımların unsurları ayrıntılı bir şekilde sunulmuştur. Böylece kurumsal yönetişim, halkla ilişkiler, yönetime katılım, kalite yönetimi, sosyal sorumluluk ve çevre duyarlılı̆̆ı gibi yeni referansların örgütleri ve yönetimleri nasıl yeniden yorumlamaya katkı sunduğu anlaşılacaktır. Anlatılan kavramsal ve kuramsal çerçeveye ek olarak uluslararası kuruluşların geliştirdikleri kurumsal sosyal sorumluluk ilkeleri incelenmiş ve Türkiye’de faaliyet gösteren kamu sektörü ve özel sektör kuruluşları üzerinde gerçekleştirilen alan araştırmasıyla Türkiye'deki KSS gelişmeleri analiz edilmiştir. Böylece Türkiye’de KSS politikası ve ilkelerinin kurumlarda ne tür etkiler ortaya koyduğu ve nasıl bir dönüşümü hareketlendirdiğine ilişkin sonuçlara ulaşılmıştır.

\section{Kavramsal Çerçeve}

\section{Sorumluluğun Sosyal Evrimi}

Sorumluluk kavramı, görev ve yetki kavramları birlikte işleyen kavramlar olarak düşünülmekte ve bunların ilişki derecelerine bağlı olarak sorumluluk artıp azalmaktadır. Ayrıca içinde bulunulan zaman, toplum ve coğrafi yapıya bağlı olarak da sorumluluk anlayışı değişik şekillerde tanımlanabilmektedir. Bu şekilde çok sayıda etkene bağlı olarak kavramın tanımı değiştiği için her durum için geçerli olacak şekilde tam bir tanım yapmak da güçleşmektedir (Özüpek, 2005, s.8).

Davis ve Blomstrom’a (1971, s.85) göre sosyal sorumluluk; karar verme sürecinde kişiselkurumsal karar ve faaliyetlerin tüm sosyal sistem üzerinde yaratacağ 1 etkileri değerlendirme zorunluluğudur.

Bir başka tanıma göre sosyal sorumluluk; bir işletmenin ekonomik ve yasal koşullara, iş ahlâkına, işletme içi ve çevresindeki kişi ve kurumların beklentilerine uygun bir çalışma stratejisi ve politikası gütmesine, insanları mutlu ve memnun etmesine yöneliktir (Eren, 1990 s.110).

Grigsby ve Stahl (1997, s.4) ise sosyal sorumluluğu; "Bir işletmenin kaynaklarını toplum yararına kullanmasıdır” şeklinde tanımlayarak kamu yararı ile ilişkisini vurgulamışlardır.

Bowen'in tanımı (aktaran Özgener, 2004, s.157) "Sosyal sorumluluk; işletmelerin gerek kendi amaçlarına, gerekse toplumsal beklentilere uygun politikalar belirleme ve uygulama, karar 
verme ve faaliyetleri yerine getirme ile toplumsal yaşamı iyileştirmeye ilişkin yükümlülüklerin bütünüdür” şeklindedir.

Daha çok işletmelere yönelik olarak geliştirilen sorumluluk kavramı, geçirdiği sosyal evrim sonucunda, toplumsal yaşamın diğer aktörleri olan ve doğaları gereği kamu yararına faaliyet gösteren kamusal kurumlar ve sivil toplum kuruluşları için de benzer anlamı taşımaktadır. Bu gelişme kamu kurum ve kuruluşlarının da sosyal sorumluluk tanımlarını politika belgelerine dahil etmesini beraberinde getirmiştir. Hem özel sektör hem de kamu sektörü kuruluşları için sosyal sorumluluk ilkeleri geliştirilmiştir.

\section{Sosyal Sorumluluğun Kurumsallaşması}

Tarihsel süreç içerisinde kurumsallaşan ve isminin başına aldığı sıfatla "Kurumsal Sosyal Sorumluluk (KSS)" olarak adlandırılan kavrama oldukça eski dönemlerde rastlamak mümkündür. $\mathrm{Bu}$ konudaki somut örnekler yazılı tarihle birlikte ortaya çıkmaktadır. Örneğin ünlü Babil Hükümdarı Hammurabi’nin Kanunları, döneminin yönetsel süreci içerisinde kurumsal sosyal sorumluluğun yerini açıcça ortaya koymaktadır. Bu kanunlar; inşaattan hekimliğe, tarımdan ticarete kadar birçok alanda toplumsal yararları bireysel çıkarlar ve hatalar karşısında koruma altına almışlardır. Bu yönüyle Hammurabi Kanunları, sosyal sorumluluğun kurumsallaşmasında önemli bir yer tutmaktadır. Modern dönemde ise KSS kavramı ilk kez 1953 yılında akademik yazında yer almıştır. Kavramı ilk kez dile getiren Bowen kitabında iş adamlarının toplumun değerleri ve toplumun ortak amaçları ile örtüşen sorumluluklarına dikkat çekmiştir (Carroll, 1999).

Araştırmalarda sosyal sorumluluğun çıkış noktası konusunda farklı yaklaşımlar mevcuttur. Bunlardan birisi, topluma fayda sağlamak üzere sosyal sorumluluğu yerine getirmenin gerekliliğinin din yoluyla da öğretildiğini savunmaktadır (Aydede, 2007, s.16). Diğer bir yaklaşım ise sorumluluk ile yasa arasında ilişki kurmaktadır. Buna göre kurumsal sosyal sorumluluk kavramı, temel olarak yasalara uyma beklentisiyle başlamakta ve bunun ötesine geçmektedir (Hirschland, 2006, s.6).

Literatürde kurumsal sosyal sorumluluk ile ilgili karşılaşılabilecek belki de en kısa tanımlardan birisi Karin Buhmann, diğeri ise Yılmaz Argüden tarafından geliştirilmiştir: Buhmann’a (2006, s.188) göre kurumsal sosyal sorumluluk, kanunlar tarafindan istenilenlerden daha fazlasını yapmaktır. Argüden'e (2002, s.5) göre ise; kurumsal sosyal sorumluluk, şirketlerin daha iyi bir toplum ve daha iyi bir çevre için gönüllü olarak katkıda bulunmalarıdır.

Kurumsal sosyal sorumluluk ile ilgili ilginç tanımlardan birisi Farmer ve Hogue tarafından yapılandır. Bahse konu tanım, bugünden geleceğe uzanan bir süreci dikkate almaktadır. Buna göre şirketlerin KSS faaliyetleri; gelecekte toplum tarafından, arzu edilen gerekli miktarda mal ve hizmetin asgari maliyet ile sağlanması için azami gayret gösterilmiş olarak algınan faaliyetlerdir (Farmer ve Hogue, 1985, s.4). Bir başka tanım ise; isteğe bağlı iş uygulamaları ve kurumsal 
kaynakların katkıları aracılığıyla toplumun refahını iyileştirmek için üstlenilen yükümlülüktür (Kotler ve Lee, 2008, s.2-3).

BM Kalkınma Programı (UNDP) Türkiye Temsilciliği tarafından 2008 yılında yayınlanan Türkiye'de Kurumsal Sosyal Sorumluluk Değerlendirme Raporu’nda kurumsal sosyal sorumluluk; "sosyal, çevresel, ekonomik ve etik kavramlarının yönetimi ve şirketlerin bu alanlarda sosyal paydaş beklentilerine olan duyarlılı̆̆ı” tanımına dayandırılmaktadır (UNDP, 2008, s.4).

Kurumsal sosyal sorumluluk, kurumların mevcut ve gelecekteki sosyal paydaşlarının beklentilerini karşılamak amacıyla süreklilik kazanan sadece zorunlu girişimler değil; gönüllü olarak topluma, çevreye sosyal ve ekonomik destek vererek yaşam kalitesini artırmaya yönelik faaliyette bulunmalarıdır (KALDER, 2006, s.3).

AB Komisyonu'na göre, daha iyi bir sosyal yaşam ve daha temiz bir çevreye katkıda bulunan bir konsept olan kurumsal sosyal sorumluluk; şirketlerin faaliyetlerinde sosyal ve çevresel anlamda ilgi ve dikkatlerini paydaşlarıyla birlikte gönüllülük temelinde bütünleştirmeleridir (Commission of The European Communities, 2001, s.4-6).

Yukarıdaki tanımlarda farklılıklar bulunmakla birlikte, dikkat çeken benzer öğeler yer almaktadır. Birincisi, kurumların ve işletmelerin faaliyet gösterdikleri alanların yanı sıra sosyal ve çevresel konularda da ilgi ve dikkatlerini yoğunlaştırmalarıdır. İkincisi, kanuni zorunluluklarının dışında toplumsal fayda sağlayacak faaliyetlerde bulunmalarıdır. Üçüncüsü, söz konusu faaliyetlerin gönüllülük esasına göre yürütülmesidir. Dördüncüsü ise, kurumsal sosyal sorumluluk olarak kabul edilecek faaliyetlerin bir defalık veya dönemsel olarak değil, sürdürülebilir olmaları zorunluluğudur.

Kurumsal sosyal sorumluluk kavramını tamamlayıcı nitelikte "Kurumsal Yönetim İlkeleri” ya da "Kurumsal Yönetişim” gibi başka kavramlar da bulunmaktadır. Ülkemizde çeşitli kuruluşlar tarafından yönetim ilkeleri ortaya konulmaktadır. Örneğin Sermaye Piyasası Kurulu (SPK) iyi kurumsal yönetim uygulamalarının temel unsurlarını eşitlik, şeffaflık, hesap verebilirlik ve sorumluluk şeklinde belirlemiştir. Eşitlik; şirket yönetiminin tüm faaliyetlerinde, pay ve menfaat sahiplerine eşit davranmasını ve olası çıkar çatışmalarının önüne geçilmesini ifade etmektedir. Şeffaflık; ticari sır niteliğindeki ve henüz kamuya açıklanmamış bilgiler hariç olmak üzere, şirket ile ilgili finansal ve finansal olmayan bilgilerin, zamanında, doğru, eksiksiz, anlaşılabilir, yorumlanabilir, düşük maliyetle kolay erişilebilir bir şekilde kamuya duyurulması yaklaşımıdır. Hesap verebilirlik, yönetim kurulu üyelerinin esas itibarıly anonim şirket tüzel kişiliğine ve dolayısıyla pay sahiplerine karşı olan hesap verme zorunluluğunu; sorumluluk ise, şirket yönetiminin anonim şirket adına yaptığı tüm faaliyetlerinin mevzuata, esas sözleşmeye ve şirket içi düzenlemelere uygunluğunu ve bunun denetlenmesini ifade etmektedir (spk.gov.tr, E.T., 2012).

Ortaya konulan bu tanımlamalar, kurumsal sosyal sorumluluk ile çok yakından ilgilidir ve tamamlar niteliktedir. 


\section{Kuramsal Çerçeve: Kurumsal Sosyal Sorumluluğun Boyutları}

Klasik ekonomi düşüncesine göre kuralları bozmadan kârları artırmak sorumluluk göstergesidir. $\mathrm{Bu}$ nedenle ilk başlarda bir şirketin kanunları ihlal etmeden ekonomik başarı göstermesi ve yardımseverlik davranışlarıyla toplumu desteklemesi yeterli görülür. 20 yy. başlarında toplumun gelişmesi ile pazardaki başarının bağlantısı ilk kez Oliver Sheldon tarafından ileri sürülmüştür. Sheldon’a göre şirketler kaynakları daha verimli kullanarak refahı arttırır. Toplumsal refah arttıkça toplumun yaşam standartlarını oluşturan etik kurallar ve adalet seviyesi artar (Ismail, 2009).

Kurumsal sosyal sorumluluk kavramının anlamı kadar içeriği de zaman içerisinde değişmiştir. İlk yıllarında yardımseverlik ile sınırlı kalan KSS anlayışı zaman içinde toplum ile iş dünyası ilişkilerine odaklanmaya başlar. Şirketin ya da kurumun belirli bir toplumsal sorunun çözümüne katkıları olarak anlaşılmaya başlar (Lee, 2008). Benzer şekilde ilk ortaya konduğunda KSS ile çevre sorunları arasında herhangi bir ilişki kurulmamıştır (Carroll, 1999, s.278-79). Zamanla bu ilişki kurulmuş ve yeni boyutlar KSS alanına girmiştir.

Bir kurum ya da işletme tarafından yürütülen çalışmaların kurumsal sosyal faaliyet olarak kabul edilebilmesi içinde bulunulan toplumun kültürel yapısına uyumuna, kurumun ya da işletmenin kimliğini yansıtmasına, itibar ve imaj yönetimine katkı sağlamasına, etik değerlerle bağdaşmasına, faaliyet alanı ile çelişki oluşturmamasına, araç değil amaç olarak kabul edilmesine bağlıdır. Dolayısıyla bir çalışmanın kurumsal sosyal sorumluluk faaliyeti olabilmesi için; bireysel ya da kurumsal anlamda toplumsal bir soruna odaklanması, belirli ve yönetilebilir bir süreci kapsaması, sürdürülebilir olması, tüm çalışanlar ve yönetim tarafından benimsenmesi, katılıma açık olması, ölçülebilmesi ve en önemlisi kalıcı değer ve fayda üretmesi gerekmektedir (www. sucsr.com, E.T., 2009).

Kurumsal sosyal sorumluluk faaliyetleri açısından yerine getirilmesi gereken dört temel sorumluluk bulunmaktadır: ekonomik, hukuki, etik ve hayırseverlik (toplumsal sorumluluk). Şekil-1'deki ${ }^{1}$ "Sosyal Sorumluluk Kategorileri”, her bir sorumluluğun göreceli büyüklüğünü de göstermektedir (Carroll, 1979, s.499). Carroll 1991 yılında yayınladığı makalesinde bu modeli “Kurumsal Sosyal Sorumluluk Piramidi” olarak göstermiştir (Idowu, 2013, s.318).

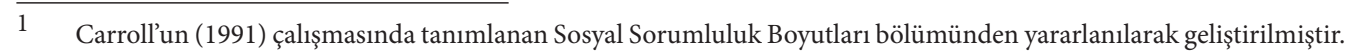




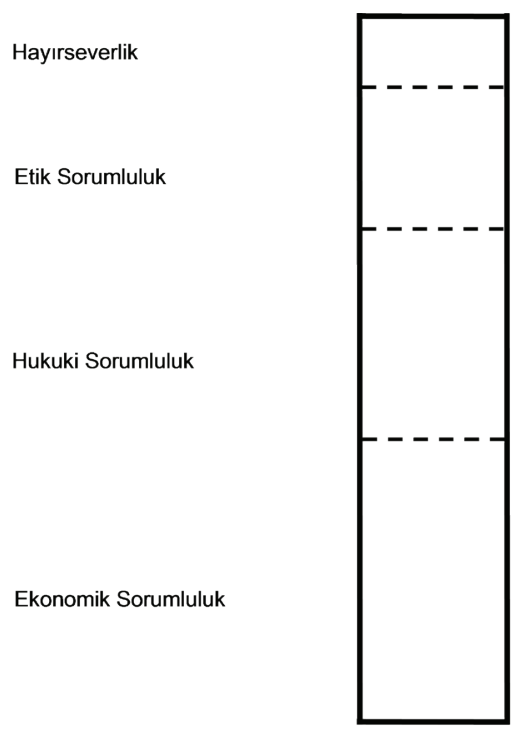

Şekil-I: Sosyal Sorumluluk Kategorileri

\section{Ekonomik Sorumluluk}

İşletmeleri, toplumda yer alan üyelerine mal ve hizmet sağlamak maksadıyla meydana getirilmiş ekonomik varlıklar olarak tanımlayan Carroll’a (1991, s.41) göre işletmelerin temel rolleri; müşterilerine ihtiyaçları ve istekleri doğrultusunda mal ve hizmet üreterek kâr sağlamaktır. Bütün kurumların ve işletmelerin ilk düzeydeki sorumluluğu, toplumun gereksinim duyduğu ve istediği mal ve hizmetleri üretmek ve temin etmek için kaynakları uzun vadede verimli bir biçimde kullanması ve ürettiklerini karlı bir biçimde satmasıdır (Boone ve Kurtz, 1999, s.13). Bu doğrultudaki faaliyetlerin yerine getirilmesinde kurumlar ve işletmeler, tüm paydaşlarına karşı ekonomik anlamda sorumludurlar.

\section{Hukuki Sorumluluk}

İşletmelerin dar anlamda paydaşlarına, geniş anlamda ise topluma karşı yükümlülükleri kârlılık beklentisinden ibaret değildir; ticari anlamda faaliyetlerini sürdürürlerken, aynı zamanda kanunlara ve yasal mevzuata uygun davranmaları gerekmektedir. Kurumsal Sosyal Sorumluluk Piramidinde yer alan boyutların oranları incelendiğinde, ekonomik sorumluluğun göreceli olarak en fazla büyüklüğe sahip olduğu görülmektedir. İşletmelerin varoluş nedenlerinin başında kâr amacının bulunması, bu büyüklüğün nedenidir. İkinci oransal büyüklük, ekonomik boyuttan sonra gelen hukuki boyuta aittir. Bunun nedeni ise, verimliliğin ve kârlılı̆̆ın yanı sıra sosyal anlamda hedefleri olan kurumların ve işletmelerin faaliyetlerini kanunlar ve yasal düzenlemeler çerçevesinde yürütmeleri yönündeki beklentinin toplumda hâkim olmasıdır. Piramidin ana 
çatısını ekonomik ve kanuni sorumluluk boyutların oluşturmasının, etik ve sosyal sorumluluk boyutlarıla karşılaştırıldıklarında boyutsal büyüklügün yaklaşı \%70'ini oluşturmalarının temelinde bu yaklaşım bulunmaktadır.

\section{Etik Sorumluluk}

Kurumsal sosyal sorumluluk piramidinde, yazılı olarak yasal bir düzenlemede yer almayan, ancak toplumsal anlamda kabul gören etik davranışlar ise diğer bir boyut olan etik sorumluluk olarak ifade edilmiştir (Carroll, 1991, s.42). Bir davranışın etik-hukuk eksenli düzlemdeki yerinin tespit edilmesinde 4 olasılık vardır: (1) Hem etik, hem de kanuni olabilir. (2) Etik olmayabilir, ancak kanuni olabilir. (3) Hem etik olmayabilir, hem de kanuni olmayabilir. (4) Etik olabilir, ancak kanuni olmayabilir.

\section{Hayırseverlik (Toplumsal Sorumluluk)}

Hayırseverlik olarak yer alan dördüncü boyut; toplumsal sorumluluk veya sosyal sorumluluk, yardımseverlik, hizmetkârlık, insanseverlik, sağduyu sorumlulukları, ihtiyari sorumluluklar vb. gibi farklı kelimelerle de isimlendirilmektedir. Carroll (1991), hayırseverlik (Filantropi) şeklinde tanımladığı ve piramidinin tepesine yerleştirdiği bu boyutu; iyi bir kurumsal vatandaş olma, tüm kaynakları toplum yararına kullanma ve böylece yaşam kalitesini yükseltme olarak yorumlamıştır.

Şirketlerin varlıklarını idame ettirebilmeleri ve sürdürülebilir başarıyı yakalayabilmeleri için, faaliyetlerini kanunlara uygun gerçekleştirmeleri, bunu yaparken etik değerlere ve toplumsal taleplere duyarlı davranmaları; karar alma, uygulama, denetleme ve raporlama çalışmalarını kurumsal sosyal sorumluluk temeline oturtmaları; ekonomik kaygıların yanı sıra kamu yararını da temel bir kriter olarak ele almaları, kısacası iyi birer kurumsal vatandaş olmaları gerekmektedir.

\section{Kurumsal Sosyal Sorumluluk Faaliyetlerine Yönelik Tartışmalar}

İşletmeler ve kurumlar açısından bakıldığında, kurumsal sosyal sorumluluk faaliyetlerinin gerek kurum ve işletme bazında, gerekse toplumsal anlamda sağladığı faydaların yanı sıra bir de maliyetleri vardır. Özellikle işletmeler açısından, Milton Friedman’ın iktisadi politika uygulamalarında para arzını önemli bir araç olarak gören monetarizmin temel ilkelerini ortaya koyduğu 1976 tarihli "Study In The Quantity Theory Of Money" (Paranın Miktar Teorisi Üzerine Çalışmalar) başlıklı kitabında yer alan ve "There is no such thing as a Free Lunch" (Bedava öğle yemeği diye bir şey yoktur) sözü ile anlamını bulan kâr maksimizasyonu yaklaşımıyla KSS’nin çeliştiği tartışmaları, kurumsal sosyal sorumluluk faaliyetlerine yönelik temel eleştiri noktasını oluşturmaktadır. Kurumsal sosyal sorumluluğun lehinde ve karşısında olan tartışmalar, Frederick, Davis ve Post'un "Business and Society: Corporate Strategy, Public Policy, Ethics" isimli kitaplarında özetle şu şekilde yer almaktadır (Frederick vd., 1988, s.35-43): 
1. Kurumsal Sosyal Sorumluluğu Destekleyen Tartışmalar:

a. Kurumların gücünü sorumluk ile dengeler.

b. Devlet müdahalesini azaltır.

c. Uzun vadede kâr elde edilmesini destekler.

ç. İşletmenin toplum karşısında imajını geliştirir.

d. Değişen toplum ihtiyaçlarına ve beklentilerine cevap verir.

e. İş tarafından yaratılmış olan sosyal problemleri düzeltir.

f. Faydalı iş kaynaklarının, zorlu problem sahalarında kullanılabilmelerini sağlar.

g. İşin ahlâki yükümlülüklerini tanımlar.

2. Kurumsal Sosyal Sorumluluğun Karşısındaki Tartışmalar:

a. Ekonomik verimliliği ve kârları düşürür.

b. Rekabet içerisindeki işletmeler arasında eşit olmayan maliyetler ortaya çıkarır.

c. Topluma gizli maliyetler çıkarır.

ç. Kurum içi kafa karışıklığı ve haksız toplumsal beklentiler yaratır.

d. İş dünyasının eline çok büyük güç verir.

e. İş dünyasının sahip olmadığı sosyal yetenekler gerektirir.

f. Sosyal anlamda hesapverebilirlikten yoksundur.

g. Bireyler yerine işletmelerin üzerine sorumluluk yükler.

Küresel rekabetin ve toplumsal bilincin gelişmesi kurumsal kararların salt ekonomik hesaplamalarla yetinerek alınmasını zorlaştırmıştır. Stratejik bakış yönetimin çok boyutlu değerlendirme yapmasını gerektirir. KSS alanında şirketin paydaşlarına odaklanan ve stratejik yönetimin paydaşlarla ilişkileri düzenlemesine yol açan teorik yaklaşım Paydaş Teorisi olarak adlandırılır. Freeman 1984 tarihli 'Strategic Management: A Stakeholder Approach' adlı eserinde paydaşları kurumun hedeflerini gerçekleştirmesinden etkilenen ya da kuruma etki edebilen kişi ya da topluluklar olarak tanımlar. Şirket ve kurumlarda paydaşlarla ilişki kurma görevini yönetici ya da yönetim kurulunun yerine getirmesi gerektiği düşünülür. Bu görevin yerine getirilmesi karar alırken paydaşların gözetilmesi ve paydaşların karar alma sürecine katkılarının sağlanması ile mümkün olur (Freeman, 2010).

Kurumsal sosyal sorumluluğun fayda-zarar analizi, klasik veya sosyo-ekonomik yaklaşımlara bağlı olarak farklı şekillerde ve farklı ağırlıklarda yorumlanabilir. Ancak toplumun bilinçlenmesi, kaynakların sınırsız olmadığının farkına varılması ve teknolojinin günlük hayatın bir parçası olmasıyla birlikte; kurumsal sosyal sorumluluğun önemi artmıştır. Kurumsal sosyal sorumluluğun ilave bir maliyet getirdiği doğrudur. Ancak yaşam kalitesinin artması, sınırlı kaynakların rasyonel kullanılması, toplumsal yaşamın kolaylaşması, kurumların ve işletmelerin çevreye ve insana verdikleri zararların önlenmesi, en azından olumsuz etkilerinin azaltılması; söz konusu ilave maliyeti kabul edilebilir kılmaktadır. 


\section{Kurumsal Sosyal Sorumluluk Çalışmalarına Yön Veren Aktörler}

İşletmeler ekonomik, çevresel ve sosyal performanslarını ölçmek amacıyla çeşitli göstergeler geliştirmektedirler. İlgili göstergelerin geliştirilmesi, izlenmesi ve raporlanması, şirketlerin müşteriler, hükümet, toplum, sivil toplum kuruluşları ve yatırımcılar nezdinde performanslarından sorumlu oldukları anlamına gelmektedir. İșletme performansını ekonomik açıdan değerlendirmeye yarayan pekçok gösterge olmakla birlikte, çevresel ve sosyal performansını değerlendirmeye yönelik modeller çok az sayıdadır. Bu alandaki çalışmaların başında Global Reporting Initiative (GRI) tarafından hazırlanmış olan Küresel Raporlama Girişimi gelmektedir (Nemli, 2004, s.35-37). 1997 yılında Boston'da kâr amacı gütmeyen bir kuruluş olan CERES (Coalition For Environmentally Responsible Economies) bünyesinde ortaya çıkan girişim 2002 yılında bağımsız bir oluşum halini almıştır (Yamak, 2007, s.145-146).

Küresel Raporlama Girişimi aracıllğıyla bir tarafta yatırımcılara ekonomik performansa ilişkin bilgi verilirken, diğer tarafta ekolojik çevrenin korunmasına yönelik faaliyetler işletmeler tarafından paydaşlarına iletilmektedir (Aktan ve Vural, 2009).

Kapsamllık, şeffaflık, doğallık ve sürekli gelişim esasına dayanan Küresel Raporlama Girişimi sürecinde yer alan ilkeleri dört ana grupta toplamak mümkündür (Argüden, 2002, s.33):

• Raporun temel özellikleri: Şeffaflık, geniş kapsam, denetlenebilirlik,

• Rapor içeriğinin kararlaştırılmasına ilişkin bilgiler: Bütünlük, uygunluk ve sürdürülebilir içerik,

- Raporun kalite ve güvenirlik sağlayacak tutarlılığa sahip olmasını sağlayacak özellikler: Doğruluk, doğallık, karşılaştırılabilirlik,

- Rapora erişim hakkında bilgiler: Netlik, güncellik.

Özetle Küresel Raporlama Girişimi; şirketlerin sundukları mal ve hizmetlerin ve çalışma koşullarının ekonomik, çevresel ve sosyal boyutlarda rapor edilmesine imkan sağlayan bir gönüllü kurumsal sosyal sorumluluk girişimidir.

Sosyal sorumluluk alanında küresel aktörlere hitap eden bir diğer çalı̧ma Uluslararası Standardizasyon Örgütünün (ISO), Sosyal Sorumluluk Rehber Dokümanını ISO 26000:2010'dur. KSS uygulamalarının doğası gereği ISO’nun standart gereklilikleri ve sertifikasyon belgelerinden farklı olarak rehberlik içerikli yön verici şekilde hazırlanmıştır. Bu açıdan bakıldığında bunun sosyal sorumluluk politikalarına katkı sağlayan bir uygulama olduğu düşünülebilir. ISO 26000 ile sosyal sorumluluk kavramlarının tanımları ve önemli konu başlıkları belirlenmiştir. Belge genel olarak karşılıklı ilişkilere odaklanır; sorumluluk uygulamalarının iş süreçleri ile bütünleştirilmesi, paydaşların belirlenmesi ve sosyal sorumluluk konularının iletişimi ile ilgili esaslar içerir (ISO, 2014).

Dünya Bankası Enstitüsü (World Bank Institute) adlı bankaya bağlı eğitim kuruluşunda sosyal sorumluluk odaklı çeşitli bilinçlendirme ve eğitim çalışmaları yürütülür. Buna ek olarak bankanın 
"Kurumsal Sosyal Sorumluluk Uygulamaları" adlı faaliyetinde küresel çapta sosyal sorumluluk ve sürdürebilirliğe verilen önemin artırılması ve uygulamaların yaygınlaştırılması hedeflenir (World Bank, 2014).

Yukarıdaki küresel ölçekli belirleyici çalışmalar ile eş güdümlü olarak Avrupa Birliğiinin kurumsal sosyal sorumluluk çalışmaları mevcuttur. Avrupa Birliği 2011-2014 Kurumsal Sosyal Sorumluluk Stratejisine göre, KSS uygulamalarının toplumun yararına hizmet etmenin yanında ticari girişimlerin çıkarlarına hizmet ettiği de vurgulanmalıdır. KSS, Avrupa 2020 Stratejisinin \%75 istihdam ile akılcı, sürdürülebilir ve kapsayıcı gelişme hedeflerini destekler. KSS değerler seti sayesinde ekonomik yapının krizlerin ve işten çıkarmaların etkilerini azaltarak çok daha dayanışmacı bir topluma ulaşmayı sağlayacağı düşünülür (European Commission, 2011, s.3).

Başta Birleşmiş Milletler ${ }^{2}$ olmak üzere uluslararası kuruluşların sosyal sorumluluğa her geçen yıl daha fazla önem verdikleri görülmektedir. Uluslararası organların çalışmaları genel olarak incelendiğinde KSS kavramına iki temel yaklaşım öne çıkmaktadır. Bunlardan birincisi, şirketlerin ve kurumların sosyal sorumluluk uygulamalarını yaygınlaştırma yönündeki çabalardır. Küresel çapta faaliyet gösteren ve böylece muazzam kaynaklara hükmeden büyük ölçekli şirketler kapsamlı ve küresel sorunlara odaklanmaya teşvik edilmektedir. Bunun yanında bazı teşvik edici faktörler ile bu uygulamaların her boyuttaki şirkete yaygınlaşması hedeflenmektedir. İlk yaklaşımla ilişkili olarak KSS uygulamalarının standartlarına ağırlık veren ikinci yaklaşım sorumluluk faaliyetlerinin görünürlügünü arttırmayı amaçlar. Böylece KSS alanındaki karşılaştırma ve araştırmaların kolaylaşması yoluyla bu uygulamaların iyileştirilmesi ve gelişmekte olan ülkelere yaygınlaştırılması hedeflenir.

\section{Kamu Yönetiminde Kurumsal Sosyal Sorumluluk}

Kârlılık, bir işletmenin doğası gereği varoluş gerekçesidir. Bu nedenle özel sektör açısından kâr etmek, süreklilik ile birlikte birinci önceliklidir. Toplumsal fayda sağlamak dolaylı bir amaç olarak kabul edilebilir. Oysa sivil toplum kuruluşlarının ${ }^{3}$ kârlılık gibi doğrudan bir amaçları bulunmamaktadır. Kâr sağlamak, ancak kendilerini sorumlu hissettikleri alandaki faaliyetlerini sürdürebilmeleri için gereksinim duyacakları bir aracın elde edilmesi anlamını taşımaktadır. Faaliyetlerinin devamlılığının sağlanması açısından süreklilik de önem arz etmektedir. Kamu sektörü açısından ise özel sektörden oldukça farklı, fakat sivil toplum kuruluşları ile benzer bir yapı söz konusudur. Asıl misyon ancak toplumsal gereksinimleri karşılamak, toplumsal

2 Birleşmiş Milletler'in öncülük ettiği Küresel İlkeler Sözleşmesi’ne ileriki bölümlerde yer verilmiştir. Çünkü bu sözleşme ilkelerinden hareketle alan araştırması yürütülmüştür.

3 Yakın zamanda yapılan çalışmalar, kurumsal sosyal sorumluluk çalışmalarının kar amacı olmayan organizasyonlar için de olumlu sonuçları olduğunu göstermektedir. Sivil toplum kuruluşları bu tip faaliyetleriyle bağışlarını artırmakta, üyelerinin bağlılığını güçlendirmekte, kamuoyunda olumlu algılar oluşturmakta, toplumdan desteğini artırmakta ve siyasal gündemi etkileyebilmektedir. Diğer taraftan, kurumsal sosyal sorumluluk daha çok kar amacı güden örgütlerle ilgili olduğu için, bunun sivil toplum kuruluşları açısından ortaya çıkaracağı etkilerin tespiti açısından daha çok araştırmaya ihtiyaç vardır (Waters ve Ott, 2014, s.3-4). 
fayda sağlamak ve hizmet üretmek olabilir. Buradaki temel kaygı, kamu yararıdır. Zira kârlılık, kaynakların toplumun ve insanlığın bugünleri ile yarınları için kullanımı anlayışılla sınırlıdır.

Kamu örgütleri, özel örgütlerin kazanç amacına karşlık hizmet amacı taşırlar. Kamu girişimleri hizmet yaparken kazansalar bile buradaki kazanç anlayışı, özel yönetimdeki kazanç amacından daha az etkilidir. Bu yüzden denebilir ki kamu yönetiminde, özel yönetimdekinden değişik olarak nicelikle değil, daha çok nitelikle ilgili bir verimlilik anlayışı egemendir (Ergun, 2004, s.16-17).

Bir taraftan kurumsal sosyal sorumluluk yaklaşımıyla topluma karşı ekonomik beklentilerin yanı sıra hukuki, etik ve sosyal değerler çerçevesinde sorumluluk duyulması anlayışı yaygınlaşırken; diğer taraftan özellikle 1980 'li yıllardan itibaren ortaya çıkan devletin sosyal niteliğini zayıflatmaya ve ortadan kaldırmaya yönelik yaklaşımlar, amaçları benzer olsa da, sonuçları bakımından toplumsal sorumluluk anlamında farklıllk göstermektedir.

Kurumsal sosyal sorumluluğun sürdürülebilir kalkınmanın sağlanması yolundaki önemine dikkat çekilen Türkiyede Kurumsal Sosyal Sorumluluk Değerlendirme Raporu’nda, kurumsal sosyal sorumluluğun kamu sektöründen özel sektöre kadar pek çok alanda kullanılabilecek bir rehber niteliği taşıdığı ifade edilmektedir (UNDP, 2008, s.2). Yine bu Rapora göre, Türkiye’de KSS üzerine yeterli yasal düzenleme yapılmamış ve KSS ile ilgili ulusal bir strateji ya da kurum oluşturulmamıştır.

Kurumsal sosyal sorumluluğu, Anayasanın 2'nci ve 5'inci maddelerinde ifadesini bulan sosyal devlet ilkesi kapsamında değerlendirmek mümkündür. Sosyal devlet; yurttaşların sosyal ve ekonomik durumları ile ilgilenen, onlara insanlık onuruna yaraşır bir yaşam düzeyi sağlamayı ödev bilen devlettir (Bozkurt vd., 1998, s.224). Kurumsal sosyal sorumluluk kavramının ve bu kapsamda yürütülen faaliyetlerin, kamu yönetiminin ruhunda var olan kamu yararı ve kamu hizmeti çerçevesinde değerlendirilmesine ilişkin yaklaşımlar mevcuttur. Özündeki "kaynakların tüm paydaşların ve toplumun genelinin beklentilerine uygun olarak toplum yararına da kullanması, kurumsal amaçlar ile toplumsal beklentilerin örtüştürülmesi, insanların yaşamının kolaylaştırılması ve yaşam kalitesi ile standartlarının artırılması" şeklinde ifade edilebilecek amaçları dikkate alındığında kurumsal sosyal sorumluluğun çıkış noktasını kamu yönetimi teşkil etmektedir. Zira Friedman’nn, iş adamlarının öncelikli sorumluluğunun kâr etmek olduğunu savunduğu özel sektör anlayışında, kâr maksimizasyonundan feragatle sosyal sorumluluk faaliyetlerine yönelme, topluma karşı hissedilen sorumluluktan kaynaklanmaktadır.

Toplumsal anlamda sorumluluğun yalnızca işletme örgütlerine özgü olmadığını belirten Can (1999, s.58); vatandaşlara en üst düzeyde özgürlük sağlama, herkese eşit firsat verme, bireylere yaşam standartlarını yükseltmede yardımcı olma gibi devlet ve hükümet örgütünün toplumsal sorumluluklarından bahsetmektedir. Bu çerçevede bazı hükümetler doğrudan sosyal faaliyetleriyle ilgili amaçlar geliştirmektedirler. Örneğin, Alman Hükümeti’nin "Sürdürülebilir Kalkınma İçin Ulusal Strateji” programı kurumsal sosyal sorumluluk kavramını kamu kurumlarında uygulamak için eylemler içermektedir. Hollandada Hükümetin görevlerinden birisi "rol model olmak için” sorumlu uygulamalar örneği ortaya koymaktadır. Yine Fransa, Birleşik Krallık ve 
Belçika gibi ülkelerde hükümetler "sürdürülebilir yeşil ihale" için hedefler belirlemektedir. Kamu sektörü örgütlerinin sosyal sorumlulukla ilişkilerine yönelik rolleri ikili bir görünüme sahiptir. Bu ikili yön içsel ve dışsal olarak kategorize edilebilir. Kamu yönetiminin “dışsal yönü”, kurumsal sosyal sorumluluğun iş dünyasında geliştirilmesini kapsamaktadır. Kamu yönetiminin “içsel yönü” ise, kamu sektörü örgütlerine sosyal olarak sorumlu örgütler gibi uygulanmaktadır. Bu sosyal sorumluluk, kamu sektörü örgütlerinin uygulamak zorunda oldukları görevlerden ve amaçlardan dolayı değil, kamu yönetiminin iç ve dış çevresiyle ilişkilerinde karşılıklı güven ve şeffaflık sağlamaya dönük çalışmalarının sonucu olarak ortaya çıkmaktadır. Bu faaliyetler bir anlamda kamu yönetimine aktarılan kaynakların etkin kullanılması ve topluma en üst düzeyde fayda sağlaması için iyi bir yapı oluşturmaktadır. Ayrıca kamu yönetiminin içsel ve dışsal sosyal sorumluluğunun denge içerisinde olması önemlidir. Çünkü bunlardan birisinin aksaması kamu yönetiminin güvenilirliğini zedeleyecektir (Hawrysz ve Foltys, 2016).

Kurumların ve işletmelerin sosyal sorumluluğu üç temel ilkeye göre belirlenebilmektedir: Meşruiyet ilkesi, kamu sorumluluğu ilkesi, yönetsel takdir edebilme ilkesi. Bunlardan kamu sorumluluğu ilkesine göre; bir kurum ya da işletme, örgütsel düzeydeki fonksiyonları itibarıyla toplumdaki birincil ve ikincil ilgi alanlarıyla ilişkili olarak sorumludur. Bu yüzden, bir kurumun ya da işletmenin sorumlulukları, faaliyetleriyle ve çıkarlarıyla ilişkili doğrudan sorunlarla sınırlı olmaktadır (Özüpek, 2005, s.15). Söz konusu tespit doğrultusunda; kamu sorumluluğunun, beraberinde kamu yararı anlayışını getirdiğini ve dolayısıyla kurumsal sosyal sorumluluğun kamu kesiminde de rahatlıkla uygulanabileceğini söylemek mümkündür.

Kamu sektörü açısından; kurumsal sosyal sorumluluğa çeşitli yasalarda yer verilmesine karşılık, kamu yönetimi tarafından kurumsal sosyal sorumluluk anlayışının çerçevesinin saptanmamış olduğu görülmektedir (Ersöz, 2007, s.136).

Aslında genel yönetim anlayışına göre, kamu sektörü ya da özel sektör örgütleri için özellikle geliştirilmiş birbirinden farklı yönetsel teknik ya da yöntemler yoktur. Yönetim evrensel bir olgudur ve fonksiyonları aynıdır. Ancak kamu yönetimindeki yönetim anlayışı, uygulama bazında özel sektör yönetiminden farklılıklar göstermektedir: (1) Siyasi organların kararlaştırdığı ve yasalarla desteklenen kamu politikaları, kamu yönetiminin içinde etkinliklerde bulunacağı çerçeveyi belirler. (2) Kamu yönetimi, kamuoyunun eleştirisine karşı hassastır, bu da kamu yönetimini daha karmaşık hale getirir. (3) Kamu yönetimi ile özel yönetim arasındaki önemli bir farklılık kâr üzerinde odaklaşır. (4) Kamu sektörü ve özel sektörün çalışma koşulları arasında farklılık vardır (Polatoğlu, 2003, s.55-56).

Bilimsel anlamda modern kamu yönetiminin tarihi, kökeni çok daha eskilere uzanmakla birlikte, Woodrow Wilson’n 1887 yılında “Political Science Quarterly”de yayınlanan “İdarenin İncelenmesi (The Study of Administration)" isimli çalışmasına dayandırılmaktadır. 1960'lara kadar kimlik arayışını geleneksel yaklaşım çerçevesinde sürdüren kamu yönetimi, bu tarihten itibaren kuramsal açıdan eleştirilere uğramıştır. 1970'li yılların ortasından 1980'lere uzanan dönemde devletlerin karşı karşıya bulundukları mali ve idari sorunlar, kamu yönetiminde verimlilik anlayışının 
gelişmesine neden olmuş, kamu yönetiminde verimliliği artırmak için özel sektörün işletmecilik tekniklerinin kullanılabileceği tezi ileri sürülmeye başlanmıştır (Leblebici vd., 2004, s.8-11). Yeni Kamu İşletmeciliği (New Public Management) paradigması olarak adlandırılan bu anlayışın yakın zamanda kamu yönetimini yeniden biçimlendirdiği ve özel sektör yönetim tekniklerini kamu yönetimine soktuğu görülmektedir. İşletmecilik reformlarıyla birlikte özelleştirme politikaları da kamu sektörünü piyasa mekanizmasıyla tanıştırmış, daha önce kamu sektörü çatısı altında mal ve hizmeti üreten birçok kurum/kuruluş artık özel sektöre geçmiştir. Bu durum kamu yönetiminin sosyal sorumluluğunun bu sektörlerde devam ettiği gerçeğini değiştirmemiştir.

Bu noktadan hareketle başlangıçta üçüncü sektör olarak adlandırılan ve gönüllülük esasına göre çalışan sivil toplum kuruluşları tarafından gündeme getirilen kurumsal sosyal sorumluluk; daha sonra özel sektör organizasyonları tarafından benimsenerek örgüt stratejisinin bir bileşeni olarak ifadesini bulmuştur. Kurumsal sosyal sorumluluk yaklaşımının ilgi ve etki alanlarının kamu yararı kavramı ile yakın ilişkisi, zaman içerisinde kamu kesiminin de konuya ilgi duymasına yol açmıştır. Hele ki özel sektör yönetimi ile kamu yönetimi arasındaki sınırların belirsizleşmesi KSS’nin kamu yönetimi örgütlerinde de görülmesini kaçınılmaz kılmaktadır. Ayrıca, kamu sektörü örgütlerinin de KSS ilkelerini içselleştirmeleri ve bu alandaki gelişmeleri takip etmeleri önemlidir. Başta özel sektör ve en az onun kadar önemli kamu sektörü örgütleri için öne çıan gelişme BM’nin öncülük ettiği Küresel İlkeler Sözleşmesi’dir.

\section{BM Küresel illkeler Sözleşmesi ve Kurumsal Sosyal Sorumluluk}

BM Küresel İlkeler Sözleşmesi, 31 Ocak 1999 tarihinde Davos’ta yapılan Dünya Ekonomik Forumu'nda, BM Genel Sekreteri Kofi Atta Annan’ın dünya genelinde önde gelen iş adamlarını, küresel bir sorumluluk anlaşmasını hem kişisel hem de uygun kamu politikalarında benimsemeye, desteklemeye ve yaymaya davet etmesiyle ortaya çıkmıştır (Argüden, 2002, s.25).

BM Küresel İlkeler Sözleşmesi (UN Global Compact); sosyal sorumlulukların en iyi ve akılcı şekilde yerine getirilmesine, şirketlerin daha güçlü bir örgütsel yapıya kavuşmalarına, uluslararası iş piyasalarında yeni bir kültürün geliştirilmesine, şirketlerin çok uluslu şirketler tarafından tercih edilen bir iş ortağı haline getirilmesine, risklere karşı proaktif davranarak risk yönetiminin gerçekleştirilmesine, kalkınma konusunda Birleşmiş Milletler’in geniş kaynaklarına ulaşılabilmesine ve çalışanların motivasyonlarının ve üretkenliklerinin, operasyonel anlamda da şirketlerin verimliliklerinin artırılmasına yardımcı olmak maksadıyla oluşturulmuş bir anlaşmadır (BM Küresel İlkeler Sözleşmesi, 1999, s.2). Sözleşme bağlayıcı değildir. Belirgin bir performans ölçütü tanımlamamakta ve bir denetleme sistemi önermemektedir. Katılımcı şirketlerin anlaşmayı ve ilkelerini duyurmaları, yılda bir kere konuyla ilgili faaliyetlerinden yola çıkarak ilerleme raporu düzenlemeleri beklenmektedir. Şirketlerin raporlarını denetleyen bir mekanizma da öngörülmemiştir. İlerleme raporlarını zamanında ya da talep edildiğinden itibaren üç ay içinde iletmeyen üyeler "Raporlarını İletmeyen Katılımcılar", iki sene rapor bildirmeyen üyeler ise "Aktif Olmayan Katılımcılar" grubuna alınmakta, Web sitesinde 
yayınlanmakta ve bu süre içinde oluşumun faaliyetlerine katılma hakkını kaybetmektedirler (Yamak, 2007, s.140-141).

Küresel İlkeler Sözleşmesi, 12 Kasım 2016 tarihi itibarılyla dünya genelinde 168 ülkeden 12.119 kurum ve şirket tarafından imzalanmış olan dünyanın en geniş kolektif vatandaşlık girişimidir. Dünya genelinde 146 kamu sektörü örgütü ve 92 kent yönetimi sözleşmeye imza koymuşlardır. Sözleşmede yer alan dört ana başlık altındaki 10 temel evrensel ilke şunlardır:

İnsan Hakları

1. İşletmeler ilan edilmiş insan haklarını desteklemeli ve bu haklara saygı duymalı.

2. Bu hakları herhangi bir biçimde suiistimal etmemeli.

Çalışma Standartları

3. İşletmeler, çalışanların toplu sözleşme ve derneklerden yararlanma haklarına izin vermeli ve bu kararı desteklemeli.

4. Zorla çalıştırma uygulamasına son verilmeli.

5. Tüm çocuk çalışanların çalıştırılmasına son verilmeli.

6. Çalışan ve iş gücündeki ayrımcılığa son verilmeli.

Çevre

7. İşletmeler çevre için önceden önlem almalı ve gerekli duyarlılığı gösterip mücadele etmeli.

8. Çevresel sorumluluğu artıracak her türlü faaliyete ve oluşuma destek vermeli.

9. Çevre dostu teknolojilerin yayılmasına ve gelişmesine yardımcı olacak her uygulamayı desteklemeli.

Yolsuzlukla Mücadele

10. İşletmeler rüşvet ve haraç dahil her türlü yolsuzlukla savaşmalı.

Birleşmiş Milletlerin 2013 yılı raporuna göre küresel ölçekte sorumlu ve sürdürülebilir ekonomik yapının oluşturulması için ilerleme kaydedilmiştir. Şirketler iyi niyetli yaklaşımlarını uygulamaya dökmeye başlamıştır. Personelin sorumluluk konusunda eğitilmesi ve KSS’un şirket politikalarına girmesi gibi uygulamalar daha hızlı gelişmektedir. Rapora göre kaynak aktarılmasını gerektiren somut uygulamalar daha yavaş gelişmektedir. Büyük ölçekli şirketler sorumluluk uygulamalarında başı çekmekte diğer firmalar ise bu uygulamaları izleyen sorumluluk faaliyetlerine girişmektedir. Şirketlerin sorumluluk algılarının geniş bir perspektifle topluma ve küresel sorunlara odaklanması umut veren bir gelişme olarak görülebilir. Özellikle büyük şirketler BM küresel gelişme hedeflerine uygun hareket etmekte ve bu hedeflere yönelik faaliyetlere ivme kazandırabilir (Hall, 2013, s.7).

BM Küresel İlkeler Sözleşmesi, özel şirketleri esas alarak oluşturulmuş olmasına rağmen halihazırda kamu sektörü örgütlerinin ve sivil toplum kuruluşlarının da Sözleşmeyi imzalamış olmaları nedeniyle kurumsal sosyal sorumluluk faaliyetleri üzerinde oldukça etkilidir. 2016 yılı 
itibarıyla Türkiye’den 251 kurum ve şirket söz konusu sözleşmeye imza koymuşlardır. Bunların önemli bölümü özel sektör ve sivil toplum kuruluşlarından oluşmaktadır. Üniversitelerden ve akademik kurumlardan Sözleşmeye imza koyanların hepsi vakıf statüsündedir. Sadece bir (1) kamu sektörü örgütü ve dört (4) kent yönetimi (yerel yönetim) Sözleşmeye imza koymuştur. Kamu kesiminden katılımın henüz yüksek düzeyde olmaması, söz konusu Sözleşmenin etki derecesinin incelenmesi gerekliliğini ortaya koymaktadır. Türkiye’deki kurumlar üzerinden yapılan alan araştırmasıyla bu etkinin sonuçları analiz edilmiştir.

\section{Türk Kamu Yönetiminde Kurumsal Sosyal Sorumluluğun Uygulamadaki Durumu}

$\mathrm{Bu}$ çalışmada, kurumsal sosyal sorumluluğun özel sektörün yanı sıra kamu kesiminde de uygulanabilirliği ve BM Küresel İlkeler Sözleşmesi ile kurumların kurumsal sosyal sorumluluğa verdikleri önem arasındaki ilişki incelenmiştir. Bunun için Türkiye’de faaliyet gösteren ve Küresel İlkeler Sözleşmesini imzalamış olan kamu sektörü örgütleri ve özel sektör kurumları çalışma kapsamına alınmıştır.

\section{Araştırmanın Yöntemi}

Araştırmanın kapsamı ve amaçlarına uygun olarak, BM Küresel İlkeler Sözleşmesi’ne üye olan bir kamu kurumu (Belediye) ve bir özel sektör kuruluşu ile üye olmayan bir kamu kurumu (Belediye) ve bir özel sektör kuruluşu örnekleme dahil edilmiştir. Bu durum kaçınılmaz olarak Araştırmanın sınırlılığını oluşturmaktadır. Zira, Türkiye’den toplamda beş kamu yönetimi kuruluşu (ki bunların dört tanesi belediyedir) Küresel İlkeler Sözleşmesini imzalamıştır. Araştırmada KSS’nin kamu yönetimi açısından uygulamadaki durumu ve etkileri analiz edilmek istendiği için karşılaştırmalı analiz tekniği tercih edilmiştir.

İlgili belediyelerin ve özel sektör kuruluşlarının tanıtımını yapmamak, kurumlararası rekabeti olumsuz etkilememek, kurumu/kuruluşu sorgulatmamak, diğer kuruluşlara karşı üstünlük veya dezavantajıyla belediyeler açısından ise siyasal anlamda bir propaganda konusu oluşturmamak üzere; BM Küresel İlkeler Sözleşmesi’ne üye olan kamu kurumu (Belediye) Kurum-A, özel sektör kuruluşu olarak Kurum-B; söz konusu sözleşmeye üye olmayan kamu kurumu (Belediye) Kurum-C, özel sektör kuruluşu Kurum-D şeklinde tanımlanmıştır.

Örneklem katılımcıları içerisine anılan kurum ve kuruluşların toplam çalışanları yerine, kurumsal sosyal sorumluluk kapsamında kabul edilen "Eğitim, Sağlık, Sanat, Kültür ve Tabiat Varlıklarının Korunması, Spor, Gıda Bankacılı̆̆ı, Bilinçlendirme Faaliyetleri, Çalışma Standartları, Gönüllü Faaliyetleri, Kurumsal Sosyal Sorumluluğun Topluma ve Kuruma Faydaları” konularında çalışanlar dahil edilmiştir. Her bir kurum veya kuruluş için ortalama 100 kişilik, toplamda 400 kişilik bir örneklem grubunun evreni yansıtacağı ve ortalamada \% 30’luk bir kapsama oranına sahip olunacağı sonucuna ulaşılmıştır. 
Araştırmada kurumların özellikleri (kamu-özel ve BM Küresel İlkeler Sözleşmesi’ne üye olanüye olmayan) önemli olduğundan dolayı anket uygulanan bireylerin kendilerine ait demografik bilgiler örneklem seçiminde dikkate alınmamıştır. Araştırma kapsamında araştırma tekniği olarak anket uygulanmıştır. Ankete katılanlar kurumlar içerisinden, kurumsal sosyal sorumluluk faaliyetlerine katılan çalışanlar arasından basit rastgele örnekleme yolu ile seçilmişlerdir.

Kurumsal sosyal sorumluluğun ve BM Küresel İlkeler Sözleşmesi’nin kamu yönetimi ile ilişkilendirilmesi çerçevesinde; doğası gereği kamu yararına yönelik faaliyet gösteren belediyeler açısından kurumsal sosyal sorumluluk olarak tanımlanabilecek etkinliklerin sınırlarının çizilmesine ihtiyaç duyulmuştur. Bu kapsamda 2005 tarih ve 5393 Sayılı Belediye Kanunu incelenmiştir. Söz konusu Kanunun genel gerekçesinde; “(...) Belediyeler bir kamu kuruluşu olarak mevzuat uyarınca birçok iş ve hizmeti serbest piyasada gördürme imkânlarına zaten sahiptir. Imtiyaz verme veya yap-işlet-devret modeliyle bazı iş ve hizmetleri yaptırma yanında Tasarıla yapılan düzenlemelere göre belediyeler birçok iş ve hizmetler bakımından yaptırma veya işlettirme yöntemlerini kullanmaya da yetkili olacaklardır. Belediyeler ayrıca diğer kamu kurum ve kuruluşları ve sivil toplum örgütleri ile işbirliği yapabilecekler; bazı hizmetlerin gördürülmesinde gönüllülük yöntemlerini uygulayacaklardır. Bu alternatif hizmet sunma yolları sayesinde belediyelerin iş görme yöntemleri çeşitlendirilerek etkinliğin sağlanmasına katkıda bulunulacaktır.(...)" ifadesi yer almaktadır.

Belediyelerin görev ve sorumluluklarını düzenleyen 14'üncü Maddenin gerekçesinde ise; “(...) Maddede, belediyelerin zorunlu görev ve yetkilerinden birkaçı sayıldıktan sonra belediyenin ekonomik durumuna ve beldenin ihtiyaçlarına göre takdire dayalı olarak yapabileceği bazı hizmetlere de değinilmiştir.(...) Belediyelerin, asli görevlerinin yanında, okul öncesi eğitim kurumları açabileceği; Devlete ait her derecedeki okul binaların yapabileceği veya bunların bakım ve onarmları ile her türlü araç, gereç ve malzeme ihtiyacını karşılayabileceği; sağlıkla ilgili her türlü tesisi açabileceği ve işletebileceği; özürlü, yaşlı ve düşü̈nlerin kolayca hizmet almasını kolaylaştıran tedbirler alacă̆ öngörülmektedir.(...)" denilmektedir.

$\mathrm{Bu}$ noktadan hareketle söz konusu maddenin "a” fikrasında belirtilen belediyenin görev ve sorumluluklarından yapılması zorunlu olacak şekilde ifade edilenler dışında kalan ve aynı maddenin "b" fikrasında yer alanların kurumsal sosyal sorumluluk kavramı kapsamında olduğu varsayımında bulunulmuştur. Zorunlu görevleri dışındaki faaliyetlerinde sorumluluk sergileyen belediyeler de, kurumsal anlamda sosyal sorumluluk sergileyen belediyeler olarak kabul edilmiştir.

Kurumsal sosyal sorumluluk kapsamında varsayılanlar belediye görevleri (Madde 14/b):

"Okul öncesi eğitim kurumları açabilir; Devlete ait her derecedeki okul binalarının inşaatı ile bakım ve onarımını yapabilir veya yaptırabilir, her türlü araç, gereç ve malzeme ihtiyaçlarını karşılayabilir; sağlıkla ilgili her türlü tesisi açabilir ve işletebilir; kültür ve tabiat varlıkları ile tarihî dokunun ve kent tarihi bakımından önem taşıyan mekânların ve işlevlerinin korunmasını 
sağlayabilir; bu amaçla bakım ve onarımını yapabilir, korunması mümkün olmayanları aslına uygun olarak yeniden inşa edebilir. Gerektiğinde, öğrencilere, amatör spor kulüplerine malzeme verir ve gerekli desteği sağlar, her türlü amatör spor karşılaşmaları düzenler, yurt içi ve yurt dışı müsabakalarda üstün başarı gösteren veya derece alan sporculara belediye meclisi kararıyla ödül verebilir. Gıda bankacılığı yapabilir.”

Çalışmanın belirli sınırlar dahilinde yapılabilmesi maksadıyla, çok geniş kapsamlı olan BM Küresel İlkeler Sözleşmesi’nde yer alan ilkelerden insan haklarına ve yolsuzlukla mücadeleye yönelik olanlar çalışma kapsamı dışında bırakılmıştır. Yine çevre ve çevre sağlığının korunması, belediyelerin asli görevlerinden olduğu için çevreye yönelik ilkeler de çalışmaya dahil edilmemiş; sadece çalışma standartlarına yönelik ilkeler çalışma kapsamına alınmıştır.

Anket soruları; konu kapsamları bakımından eğitim, sağlık, sanat, kültür ve tabiat varlıklarının korunması, spor, gıda bankacılığı, bilinçlendirme, çalışma standartları, gönüllü faaliyetleri ve kamuda sosyal sorumluluğun topluma ve kuruma faydaları olmak üzere 10 ayrı grup altında değerlendirilmiştir. Beşli Likert Ölçeği ile değerlendirilen anket örneği EK-1'de yer almaktadır. Tablo-1, ölçülmek istenen boyutları temsil eden soru gruplarını ve anket güvenilirlik analizini göstermektedir. Bu boyutların tümünün kurumsal sosyal sorumluk kapsamında katkısı olduğu düşünülmektedir. İlk 9 boyut kurumsal sosyal sorumluluk alanında yapılabilecek faaliyetler ve bu konuda kurumların yaklaşımlarını ele alırken; 10'ncu boyut olan "Kurumsal Sosyal Sorumluluğun Topluma ve Kuruma Faydaları" boyutu diğerlerinden farklılık arz ederek kurumsal sosyal sorumluluğa yönelik bir faaliyeti ele almamakta, ancak kurumda bu konuda çalışan personelin konuya bakış açısını değerlendirmektedir. Boyutların katkısını doğrusal bir modelde değerlendirmek yerine her birinin kendi özelliğine göre bir önemi olduğu düşünülerek hepsinin birlikte kurumsal sosyal sorumluluğa katkısının var olduğu kıymetlendirilmiştir. Ayrıca, her bir boyutu birden fazla soru ile ölçerek anketin deneysel hatasının azaltılması hedeflenmiştir. Ölçülmek istenen boyutlar, ilgili soru grubundaki cevapların ortalamalarının alınması suretiyle analiz edilmiştir.

Tablo-I: Soru Grupları ve Anket Güvenilirlik Analizi

\begin{tabular}{|c|l|c|c|c|}
\hline \multicolumn{1}{|c|}{ Soru Grubu } & Sorular & Cronbach's Alpha & Ortalama \\
\hline 1 & Eğitim & $1,2,3$ & $\mathbf{0 . 8 4 5}$ & 3.708 \\
\hline 2 & Sağllk & $4,5,6$ & $\mathbf{0 . 8 3 2}$ & 3.175 \\
\hline 3 & Sanat & $7,8,9,10$ & $\mathbf{0 . 9 5 4}$ & 3.951 \\
\hline 4 & Kültür ve Tabiat Varlıklarının Korunması & $11,12,13,14$ & $\mathbf{0 . 8 7 1}$ & 3.406 \\
\hline 5 & Spor & $15,16,17$ & $\mathbf{0 . 7 8 9}$ & 3.283 \\
\hline 6 & Gida Bankacıllğı & $18,19,20$ & $\mathbf{0 . 7 4 4}$ & 3.051 \\
\hline 7 & Bilinçlendirme & $21,22,23$ & $\mathbf{0 . 8 9 5}$ & 3.017 \\
\hline 8 & Çalışma Standartları & $24,25,26,27$ & $\mathbf{0 . 8 3 1}$ & 3.244 \\
\hline 9 & Gönüllü Faaliyetleri & $28,29,30,31$ & $\mathbf{0 . 8 2 5}$ & 3.594 \\
\hline \multirow{2}{*}{10} & $\begin{array}{l}\text { Kamuda Sosyal Sorumluluğun Topluma ve } \\
\text { Kuruma Faydaları }\end{array}$ & $32,33,34,35,36,37$ & $\mathbf{0 . 8 8 3}$ & 3.646 \\
\hline
\end{tabular}


Hazırlanan anketin ön testi yapılarak, soru gruplarının (anket sonucuna etki eden faktörlerin) içerdikleri çeşitli sorular ile birlikte ölçülmek istenilen hususları tutarlı bir şekilde ölçtüğü, anketin güvenilir ve geçerli olduğu görülmüștür.

\section{Araştırmanın Bulguları ve Sonuçların Analizi}

$\mathrm{Bu}$ Araştırmada, kurumsal sosyal sorumluluğun özel sektörün yanı sıra kamu yönetiminde de uygulanabilirliğinin ve BM Küresel İlkeler Sözleşmesi ile kurumların kurumsal sosyal sorumluluğa verdikleri önem arasında anlamlı bir ilişki bulunup bulunmadığının saptanması maksadıyla iki farklı hipotezin testi yapılmıştır.

Birinci olarak; kurumsal sosyal sorumluluğun özel sektörün yanı sıra kamu kesiminde de uygulanabilirliğini test etmek için aşağıdaki hipotez oluşturulmuştur.

$\mathrm{H}_{\mathrm{o}}$ : Kamu kurumlarının ortalamaları, özel şirket ortalamalarına eşittir.

$\mathrm{H}_{1}$ : Kamu kurumları ortalamaları, özel şirket ortalamalarından farklıdır.

İkinci olarak; "BM Küresel İlkeler Sözleşmesi ile kurumların kurumsal sosyal sorumluluğa verdikleri önem arasında anlamlı bir ilişki vardır.” savını test etmek için aşağıdaki hipotez oluşturulmuştur.

$\mathrm{H}_{\mathrm{o}}$ : BM Küresel İlkeler Sözleşmesi’ne üye kurumların ortalamaları, üye olmayan kurumların ortalamalarına eşittir.

$\mathrm{H}_{1}$ : BM Küresel İlkeler Sözleşmesi’ne üye kurumların ortalamaları, üye olmayan kurumların ortalamalarından farklıdır.

Kamu ve özel kurumlar arasındaki farklar ile BM Küresel İlkeler Sözleşmesi’ne üye olan ve olmayan kurumlar arasındaki farklar incelendiğinden, iki faktör (kurumun kamu kurumu olma veya olmama faktörü, kurumun BM Küresel İlkeler Sözleşmesi’ne üye olma veya olmama faktörü) ayrı ayrı ANOVA testinde kullanılmıştır.

\section{Kamu ve Özel Sektör Karşılaştırması}

Soru gruplarının kamu ve özel sektör karşılaştırmasına yönelik ortalamaları Grafik-1'de yer almaktadır. 
Grafik-I: Soru Gruplarının Kamu ve Özel Sektör Ortalamaları

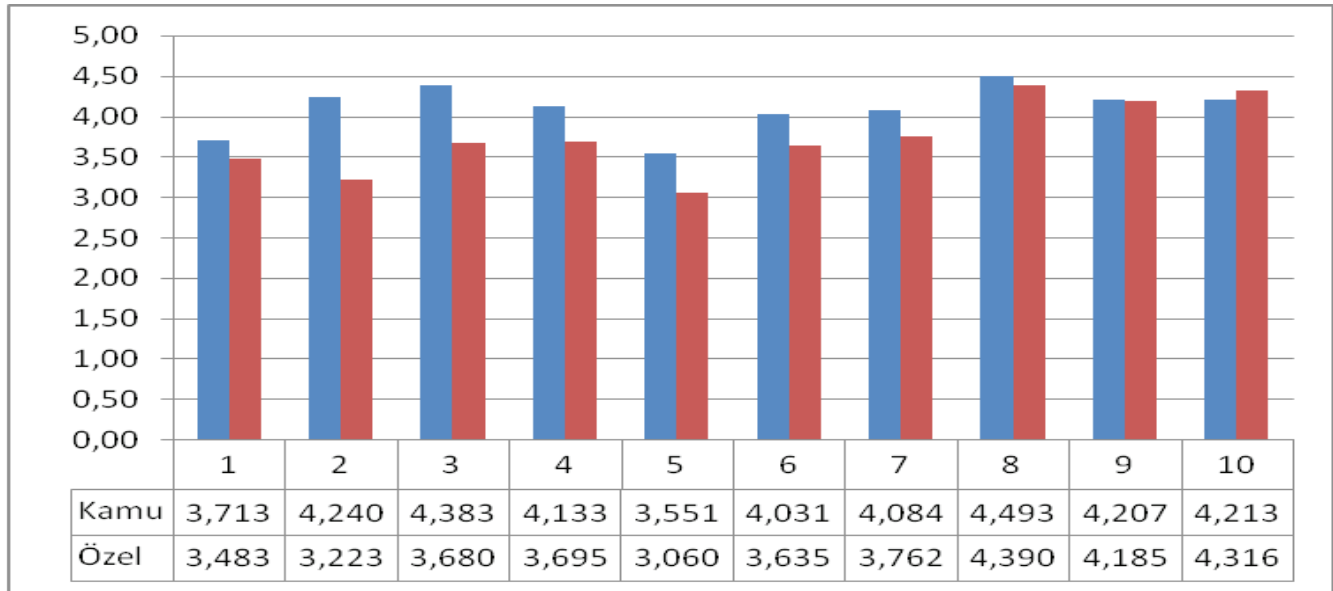

Buna göre özellikle devlet tarafından yürütülmesi beklenen eğitim, sağlık, sanat, kültür ve tabiat varlıklarının korunması, spor, gıda bankacılığı, bilinçlendirme gruplarında kamu kesimi ortalaması; çalışma standartları, gönüllü faaliyetleri ve kurumsal sosyal sorumluluğun topluma ve kuruma faydalarının yer aldığı gruplarda özel sektör ortalaması daha yüksektir.

Soru gruplarının Kamu ve Özel Sektör Karşılaştırmasına Yönelik Anova Testi Sonuçları Tablo2’de yer almaktadır. Buna göre eğitim, sağlık, sanat, kültür, spor, gıda bankacılı̆̆ı, bilinçlendirme faaliyetleri gruplarında kamu kurum ortalamalarının özel kurum ortalamalarından anlamlı bir şekilde farklı (yüksek) olduğu; kurumsal sosyal sorumluluğun topluma ve kuruma faydaları grubunda yine anlamlı bir şekilde farklı (düşük) olduğu; çalışma standartları ve gönüllü faaliyetleri gruplarında ise anlamlı bir farklılık bulunmadığı (eşit olduğu) görülmüştür.

Kamu kurumlarında soru grubu ortalamalarının birbirleri ile uyumlu oldukları, özel kurumlarda ise kişilerin soru gruplarına yaklaşımlarının birbirlerinden nispeten bağımsız oldukları gözlenmiştir. 
Tablo-2: Kamu ve Özel Sektör Karşılaştırması Anova Testi Sonuçları

\begin{tabular}{|c|c|c|c|c|c|c|}
\hline Dependent Variable & & $\begin{array}{l}\text { Sum of } \\
\text { Squares }\end{array}$ & df & $\begin{array}{l}\text { Mean } \\
\text { Square }\end{array}$ & F & Sig. \\
\hline \multirow{2}{*}{ Eğitim } & Contrast & 3.5267 & 1 & 3.5267 & 2.9532 & 0.0292 \\
\hline & Error & 355.8700 & 298 & 1.1942 & & \\
\hline \multirow{2}{*}{ Sağlık } & Contrast & 69.3600 & 1 & 69.3600 & 80.4764 & 0.0000 \\
\hline & Error & 256.8367 & 298 & 0.8619 & & \\
\hline \multirow{2}{*}{ Sanat } & Contrast & 33.1350 & 1 & 33.1350 & 46.8828 & 0.0000 \\
\hline & Error & 210.6150 & 298 & 0.7068 & & \\
\hline \multirow{2}{*}{$\begin{array}{l}\text { Kültür ve Tabiat Varlıklarının } \\
\text { Korunması }\end{array}$} & Contrast & 12.9801 & 1 & 12.9801 & 18.5255 & 0.0000 \\
\hline & Error & 208.7972 & 298 & 0.7007 & & \\
\hline \multirow{2}{*}{ Spor } & Contrast & 16.4452 & 1 & 16.4452 & 13.9444 & 0.0002 \\
\hline & Error & 351.4422 & 298 & 1.1793 & & \\
\hline \multirow{2}{*}{ Gıda Bankacılı̆̆ı } & Contrast & 25.0785 & 1 & 25.0785 & 27.9172 & 0.0000 \\
\hline & Error & 267.6989 & 298 & 0.8983 & & \\
\hline \multirow{2}{*}{ Bilinçlendirme } & Contrast & 7.7067 & 1 & 7.7067 & 7.4923 & 0.0066 \\
\hline & Error & 306.5244 & 298 & 1.0286 & & \\
\hline \multirow{2}{*}{ Çalışma Standartları } & Contrast & 1.0209 & 1 & 1.0209 & 1.7400 & 0.1882 \\
\hline & Error & 174.8491 & 298 & 0.5867 & & \\
\hline \multirow{2}{*}{ Gönüllï Faaliyetleri } & Contrast & 0.8067 & 1 & 0.8067 & 1.5980 & 0.2072 \\
\hline & Error & 150.4275 & 298 & 0.5048 & & \\
\hline \multirow{2}{*}{$\begin{array}{l}\text { KSS'nin Topluma ve Kuruma } \\
\text { Faydaları }\end{array}$} & Contrast & 2.1400 & 1 & 2.1400 & 1.8543 & 0.1224 \\
\hline & Error & 136.8918 & 298 & 0.4594 & & \\
\hline
\end{tabular}

Kamu kurumlarında genel olarak kurumsal sosyal sorumluluk ile ilgili soru gruplarının bir bütünlük içerisinde yüksek oldukları, soru gruplarının temsil ettikleri faaliyetlerin bütün olarak algılandıkları; ancak özel şirketlerde bu faaliyetlerin birbirlerinden bağımsız olarak değerlendirildiği, kurumsal sosyal sorumlulukla ilgili faaliyetlerde belirli konulara odaklandıkları, bu faaliyetlerin tümüne birden aynı şekilde önem vermeyebildikleri değerlendirilmiştir. Bu durum, özel şirketlerde kurumsal sosyal sorumluluk için ayrılan bütçenin, söz konusu faaliyetlerin daha etkili olması için belirli konulara odaklanabileceği; ama kamu kurumlarında bütçe ve gayretlerin eşit dağılımının ön plana çıkmış olabileceği olarak kıymetlendirilmektedir. Ayrıca hem kamu kurumlarında, hem de özel şirketlerde eğitim ve sağlık ile ilgili cevapların korelasyonlarının 
yüksek olduğu, dolayısıyla bu iki konudaki faaliyetlerin her iki gruptaki kurum ve şirketlerde de birbirleri ile örtüşen, tamamlayıcı faaliyetler olarak görülebildiği değerlendirilmektedir. Bunun dışında, kamu kurumlarında da gıda bankacılığı, bilinçlendirme ve çalışma standartları soru gruplarında korelasyonların nispeten daha düşük olduğu görülmüştür. Bunun nedeninin de, bu soru grupları ile ilgili faaliyetlerin daha az somut ve nispeten daha az gözlemlenen faaliyetler olmasından kaynaklandığı kıymetlendirilmektedir.

Genel olarak; kamu kurumlarının soru grubu ortalamalarının en az özel kurum ortalamaları kadar ve çoğu boyutlarda daha yüksek olduğu, soru gruplarının temsil ettikleri faaliyet alanlarının daha fazla bütünsellik göstermesi gibi hususlar bakımından kurumsal sosyal sorumluluk ile ilgili olarak bu çalışma kapsamında tespit edilen başlıklarda daha olumlu sonuçlar verdiği sonucuna ulaşılmaktadır.

\section{BM Küresel IIlkeler Sözleşmesi'ne Üye Olan ve Olmayan Kurumlar ve Şirketlerin Karşılaştırması}

Soru gruplarının BM Küresel İlkeler Sözleşmesi’ne üye olan ve olmayan kurumlar ve şirketlerin karşılaştırmasına yönelik ortalamaları Grafik-2'de yer almaktadır.

Grafik-2: Soru Gruplarının BM Küresel Illkeler Sözleşmesi’ne Üye Olma ve Olmama Ortalamaları

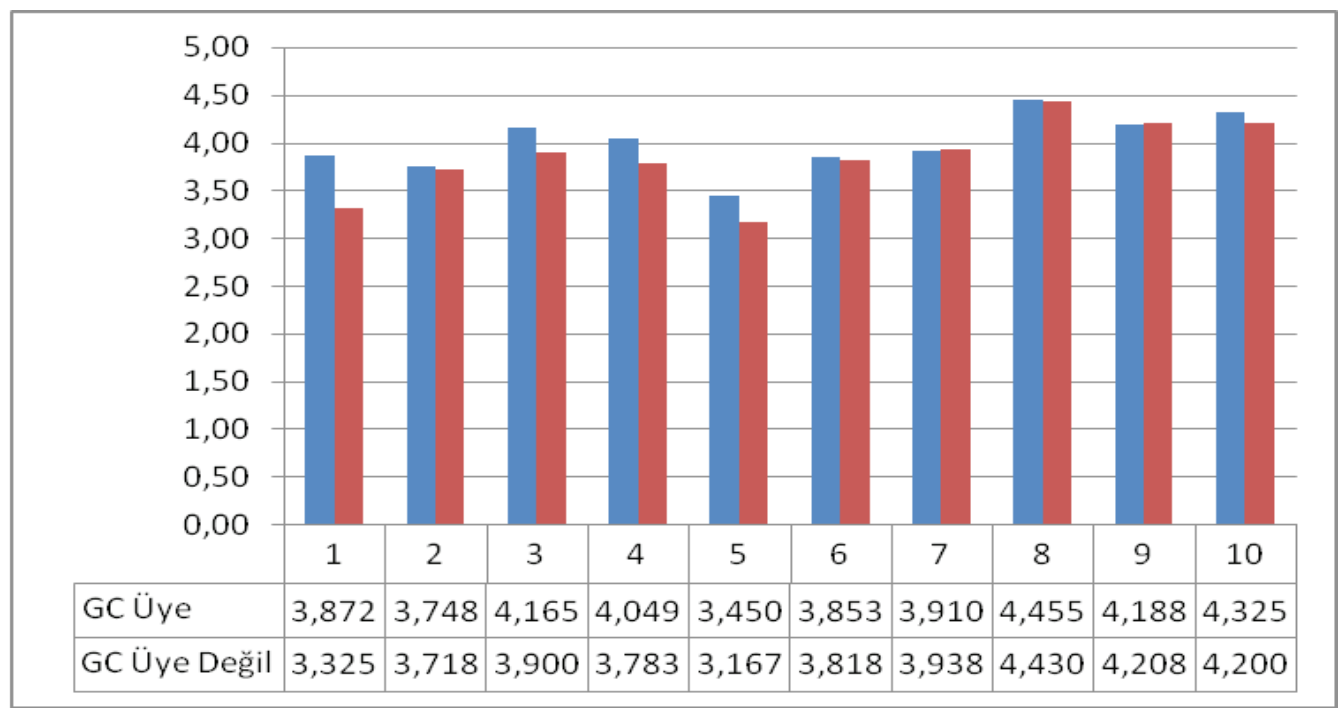

Kamu ve özel sektör karşılaştırmasındaki gibi eğitim, sağlık, sanat, kültür ve tabiat varlıklarının korunması, spor, gıda bankacılığı, bilinçlendirme gruplarında BM Kurumsal İlkeler Sözleşmesi’ne üye kuruluşların; çalışma standartları, gönüllü faaliyetleri ve kurumsal sosyal sorumluluğun kuruma ve topluma faydaları gruplarında ise üye olmayan kuruluşların ortalaması daha yüksektir. 
BM Küresel İlkeler Sözleşmesi’ne Üye Olma ve Olmama Karşılaştırmasına Yönelik Anova Testi Sonuçları Tablo-3’te yer almaktadır. Buna göre eğitim, sanat, kültür, spor gruplarında BM Küresel İlkeler Sözleşmesi’ne üye kuruluşların ortalamalarının, üye olmayanların ortalamalarından anlamlı bir şekilde farklı (yüksek) olduğu; sağlık, gıda bankacılığı, bilinçlendirme faaliyetleri, çalışma standartları, gönüllü faaliyetleri ve kurumsal sosyal sorumluluğun topluma ve kuruma faydaları gruplarında ise anlamlı bir farklılık bulunmadığı (eşit olduğu) görülmüştür. Soru grupları BM Küresel İlkeler Sözleşmesi’ne üye olan ve olmayan kuruluşlar bakımından analiz edildiğinde; genel olarak Sözleşmeye üye olan ve olmayan kuruluşlar arasındaki farkların, kamu kurumları-özel şirketler arasındaki farklardan daha düşük olduğu gözlenmiştir.

Tablo-3: BM Küresel İlkeler Sözleşmesi'ne Üye Olma ve Olmama Karşılaştırmasına Yönelik Anova Testi

\begin{tabular}{|c|c|c|c|c|c|c|}
\hline \multicolumn{7}{|c|}{ Sonuçları } \\
\hline Dependent Variable & & $\begin{array}{l}\text { Sum of } \\
\text { Squares }\end{array}$ & df & $\begin{array}{l}\text { Mean } \\
\text { Square }\end{array}$ & F & Sig. \\
\hline \multirow{2}{*}{ Eğitim } & Contrast & 58.2817 & 1 & 58.2817 & 57.6787 & 0.0000 \\
\hline & Error & 301.1150 & 298 & 1.0105 & & \\
\hline \multirow{2}{*}{ Sağlık } & Contrast & 20.5350 & 1 & 20.5350 & 20.0203 & 0.747 \\
\hline & Error & 305.6617 & 298 & 1.0257 & & \\
\hline \multirow{2}{*}{ Sanat } & Contrast & 37.5000 & 1 & 37.5000 & 54.1818 & 0.0000 \\
\hline & Error & 206.2500 & 298 & 0.6921 & & \\
\hline \multirow{2}{*}{$\begin{array}{l}\text { Kültür ve Tabiat Varlıklarının } \\
\text { Korunması }\end{array}$} & Contrast & 25.6267 & 1 & 25.6267 & 38.9331 & 0.0000 \\
\hline & Error & 196.1506 & 298 & 0.6582 & & \\
\hline \multirow{2}{*}{ Spor } & Contrast & 30.2252 & 1 & 30.2252 & 26.6749 & 0.0000 \\
\hline & Error & 337.6622 & 298 & 1.1331 & & \\
\hline \multirow{2}{*}{ Gıda Bankacılığı } & Contrast & 0.1157 & 1 & 0.1157 & 0.1179 & 0.7316 \\
\hline & Error & 292.6617 & 298 & 0.9821 & & \\
\hline \multirow{2}{*}{ Bilinçlendirme } & Contrast & 0.7350 & 1 & 0.7350 & 0.6987 & 0.4039 \\
\hline & Error & 313.4961 & 298 & 1.0520 & & \\
\hline \multirow{2}{*}{ Çalışma Standartları } & Contrast & 0.9600 & 1 & 0.9600 & 1.6356 & 0.2019 \\
\hline & Error & 174.9100 & 298 & 0.5869 & & \\
\hline \multirow{2}{*}{ Gönüllü Faaliyetleri } & Contrast & 0.0651 & 1 & 0.0651 & 0.1283 & 0.7204 \\
\hline & Error & 151.1691 & 298 & 0.5073 & & \\
\hline \multirow{2}{*}{$\begin{array}{l}\text { KSS'nin Topluma ve Kuruma } \\
\text { Faydaları }\end{array}$} & Contrast & 2.8474 & 1 & 2.8474 & 6.2307 & 0.0505 \\
\hline & Error & 136.1844 & 298 & 0.4570 & & \\
\hline
\end{tabular}


Ankette incelenen boyutlara verilen cevapların ortalamaları bakımından genel olarak; bir kurumun kamu kurumu olmasının, BM Küresel İlkeler Sözleşmesi’ne üye olmasından daha fazla fark yaratan bir unsur olduğu tespit edilmiştir. BM Küresel İlkeler Sözleşmesi’ne üye olan ve olmayan kuruluşlar incelendiğinde sadece 4 boyutta (eğitim, sanat, kültür ve tabiat varlıklarının korunması, spor) anlamlı bir fark olduğu, diğer boyutlarda anlamlı bir fark olduğunun söylenemeyeceği sonucuna ulaşılmıştır.

BM Küresel İlkeler Sözleşmesi’ne üye olan ve olmayan kuruluşların cevaplarının kendi içlerinde soru grubu aralarındaki korelasyonları incelendiğinde ise; hem BM Küresel İlkeler Sözleșmesi’ne üye olan hem de olmayan kuruluşlarda verilen cevaplarda eğitim ve sağlık ile ilgili cevapların korelasyonlarının yüksek olduğu, yani bu iki konudaki faaliyetlerin her iki gruptaki kuruluşlarda da birbiri ile örtüşen, tamamlayıcı faaliyetler olarak görülebildiği değerlendirilmektedir. Bunun yanında, sanat boyutunun diğer boyutlar ile korelasyonlarının nispeten daha düşük olduğu görülmüştür. Bunun nedeninin de, sanatsal faaliyetlere ağırlık verdiğini belirten kuruluşun diğer faaliyetlere aynı doğrultuda eğilmemiş olabileceği olarak kıymetlendirilmektedir.

Anketteki boyutların karşılaştırılmalarında özellikle dikkat çekici olarak;

* Tüm kurumlarda (kamu kurumları, özel şirketler, BM Küresel İlkeler Sözleşmesi’ne üye olan ve olmayan kuruluşlar);

- Çalışma standartları boyutu ortalamalarının en yüksek ortalamalar olduğu,

- Spor boyutu ortalamalarının ise en düşük ortalamalar olduğu,

- Eğitim boyutu ortalamalarının genelde düşük olduğu (kamu kurumları ve BM Küresel İlkeler Sözleşmesi’ne üye olmayan kuruluşlarda en düşük 2'nci, özel şirketlerde en düşük 3'üncü, BM Küresel İlkeler Sözleşmesi’ne üye kuruluşlarda ise en düşük 4’üncü boyut olduğu),

Sağlık boyutu ortalamalarının ise, özel şirketlerde ve BM Küresel İlkeler Sözleşmesi’ne üye kuruluşlarda en düşük 2'nci, BM Küresel İlkeler Sözleşmesi’ne üye olmayan kuruluşlarda da en düşük 3’üncü boyut olmasına rağmen, kamu kurumlarında en yüksek 3'üncü boyut olduğu,

* Kurumsal sosyal sorumluluğun dört temel boyutundan birisini teşkil eden gönüllü faaliyetlerinin genelde ortalama değerler açısından 10 boyut arasında ilk 5 grup içerisinde yer aldığı (kamu kurumlarında en yüksek 5’inci boyut iken, özel şirketlerde ve BM Küresel İlkeler Sözleşmesi’ne üye kuruluşlarda en yüksek 3’üncü, BM Küresel İlkeler Sözleşmesi’ne üye olmayan kuruluşlarda ise en yüksek 2'nci boyut olduğu) görülmektedir.

Analizler sonucunda; "Kurumsal sosyal sorumluluk, özel sektörün yanı sıra kamu kesiminde de uygulanabilir." şeklindeki ana hipotezde $\mathrm{H}_{\mathrm{o}}$ ’n eğitim, sağlık, sanat, kültür ve tabiat varlıklarının korunması, spor, gıda bankacılığı ve bilinçlendirme faaliyetleri boyutları için reddedilebileceği; yani kamu kurumları ve özel şirketlerin eşit olduğunun söylenemeyeceği görülmektedir. Diğer boyutlar (çalışma standartları, gönüllü faaliyetleri ve kurumsal sosyal sorumluluğun topluma ve 
kuruma faydaları) için $\mathrm{H}_{\mathrm{o}}$ ’n reddedilemeyeceği, yani kamu kurumlarının ve özel şirketlerin eşit olduğunun söylenebileceği tespit edilmiştir.

Kamu kurumları ve özel şirketler boyut ortalamaları tek tek karşılaştırıldığında; kamu kurum ortalamalarının yalnızca kurumsal sosyal sorumluluğun topluma ve kuruma faydaları boyutunda düşük olduğu, ancak ANOVA Testi sonuçlarına göre anlamlı olmadığı görülmüştür. "BM Küresel İlkeler Sözleşmesi ile kurumların kurumsal sosyal sorumluluğa verdikleri önem arasında anlamlı bir ilişki vardır." şeklindeki diğer hipotezde $\mathrm{H}_{\mathrm{o}}$ ’n eğitim, sanat, kültür ve tabiat varlıklarının korunması ve spor boyutları için reddilebileceği; yani Sözleşmeye üye olan ve üye olmayan kuruluşların eşit olduğunun söylenemeyeceği tespit edilmiştir. Diğer boyutlar (sağlık, gıda bankacılı̆̆g, bilinçlendirme, çalışma standartları, gönüllü faaliyetleri ve kurumsal sosyal sorumluluğun topluma ve kuruma faydaları) için $\mathrm{H}_{\mathrm{o}}$ 'n reddedilemeyeceği; yani Sözleşmeye üye olan ve üye olmayan kuruluşların eşit olduğunun söylenebileceği tespit edilmiştir. BM Küresel İlkeler Sözleşmesi’ne üye olan ve olmayan kuruluş boyut ortalamaları karşılaştırıldığında, Sözleşmeye üye olan kuruluş ortalamalarının hiç bir boyutta anlamlı şekilde düşük olmadığı görülmüştür.

\section{Sonuç ve Değerlendirme}

Şirketlerin topluma ve insanlığa karşı sorumlulukları vardır ve bu sorumluluklar uzun vadelidir. İşletmeler açısından başarı, içinde bulundukları topluma karşı ödev, görev ve sorumluluklarını yerine getirmek, çalışanların çıkarlarını, toplumun çıkarlarını ve elbette işletmelerinin çıkarlarını korumak ve bunlar arasında denge kurmak ile mümkündür. Bu da kurumsal sosyal sorumluluk ruhunu taşımakla olabilmektedir (Özgen, 2006, s.51). Toplumsal sorumluluk yalnızca işletmelere özgü değildir; devlet ve hükümet örgütünün, anayasada belirlenmiş şekilde, vatandaşlara en üst düzeyde özgürlük sağlama, herkese eşit fırsat verme, bireylerin yaşam standartlarını yükseltme sorumlulukları bulunmaktadır (Can, 1999, s.58). BM Türkiye Koordinatörlüğü ve BM Kalkınma Programı (UNDP) Temsilciliği tarafından 2008 yılında yayınlanan “Türkiye’de Kurumsal Sosyal Sorumluluk Değerlendirme Raporu”nda, bütünlüklü bir strateji belirlenerek kurumsal sosyal sorumluluğun sürdürülebilirliğini mümkün kılmak için devletin kurumsal sosyal sorumluluk politikaları oluşturmasına ve sürece dahil olmasına ihtiyaç duyulduğu belirtilmektedir. Kurumsal sosyal sorumluluğun başrolündeki aktörlerden birisi olan devlet; hukuki ve ekonomik esasların saptanmasında belirleyici olduğuna ve kamu yararı ilkesinden hareketle etik ile sosyal sorumluluk boyutlarındaki uygulamaların da içerisinde bulunduğuna göre kurumsal sosyal sorumluluk, kamu kesiminde de uygulanabilir.

Diğer taraftan belediyeler; özel kesimin kâr maksimizasyonu olan amaç ve beklentisiyle, toplumsal beklentilerin karşılanmasında sorumluluk almasının beklenmesinin doğru olmadığını, bu nedenle özellikle yerel yönetimlerden başlanarak kamu ve özel kesimin insan odaklı çözüm üretim sürecine uyum göstermelerinin, paylaşılan ortak sorunlar ve toplumsal beklentiler için çözümler üretilmesinin ve faaliyete geçilmesinin gerektiğini ifade etmektedirler. Kamu yönetiminin bir parçası olan belediyeler, sosyal sorumluluk projelerinin sadece özel 
kesim tarafından yerine getirilmesinin doğru olmadığını, bu konuda kamu yönetiminin de inisiyatif alarak kurumsal sosyal sorumluluk faaliyetlerini planlaması ve uygulaması gerektiğini vurgulamaktadırlar. Söz konusu yaklaşım ve bu yaklaşım doğrultusunda yürütülen çalışmalar, kurumsal sosyal sorumluluğun, özel sektörün yanı sıra kamu yönetiminde de uygulanabileceğini göstermektedir.

$\mathrm{Bu}$ çalışma; kurumsal sosyal sorumluluğun özel sektörün yanı sıra kamu sektöründe de uygulanabileceğini ve dünya genelindeki en yaygın kolektif vatandaşlık girişimi olması nedeniyle BM Küresel İlkeler Sözleşmesi ile kurumların kurumsal sosyal sorumluluğa verdikleri önem arasında anlamlı bir ilişkinin bulunduğunu incelemektedir. İlgili alanların çok geniş olması nedeniyle "eğitim, sağlık, sanat, kültür ve tabiat varlıklarının korunması, spor, gıda bankacılığı, bilinçlendirme faaliyetleri, çalışma standartları, gönüllü faaliyetleri, kurumsal sosyal sorumluluğun topluma ve kuruma faydaları" çalışma sahası olarak kabul edilmiştir. Kamu kurumlarının soru grubu ortalamalarının en az özel kurum ortalamaları kadar ve çoğu boyutlarda daha yüksek olduğu, soru gruplarının temsil ettikleri faaliyet alanlarının daha fazla bütünsellik göstermesi bakımından bu çalışma kapsamındaki başlıklarda daha olumlu sonuçlar verdiği saptanmıştır. BM Küresel İlkeler Sözleşmesi’ne üye olan ve olmayan kuruluş boyut ortalamaları karşılaştırıldığında ise, üye olan kuruluş ortalamalarının hiç bir boyutta anlamlı şekilde düşük olmadığı görülmüştür. Bu nedenlerle; yapılan anket verileri ile yapılan analiz doğrultusunda kurumsal sosyal sorumluluğun, özel şirketlerde olduğu kadar kamu kurumlarında da uygulanabileceği; BM Küresel İlkeler Sözleşmesi’ne üye olma ile kurumsal sosyal sorumluluğa önem verme arasında pozitif bir etki olabileceği sonucuna ulaşılmıştır.

Sonuç olarak kurumsal sosyal sorumluluk çalışmalarının yalnız özel sektöre bırakılması doğru değildir; kamu kurumlarının aktif rol oynaması gerekmektedir. İngiltere’de olduğu gibi, Türkiye’de de kurumsal sosyal sorumluluk ilkelerini, usul ve yöntemlerini belirleyecek, bu alandaki çalışmaları yönlendirecek ve koordine edecek bir Kurumsal Sosyal Sorumluluk Bakanlığı̀nın kurulması hususunun ve getireceği yararlar ile mahzurlarının tartışılmasının yararlı olacağı değerlendirilmektedir.

Ayrıca kurumsal sosyal sorumluluğun kurumların ve işletmelerin misyonu, vizyonu ve değerlerinde yer alması, örgüt kültürü ve örgüt ikliminde kurumsal sosyal sorumluluğa yer verilmesi, tepe yönetime bağlı bir kurumsal sosyal sorumluluk bölümünün oluşturulması, kurumsal sosyal sorumluluk çalışmalarına ayrı bütçe ve kaynak ayrılması, ekonomik ve sosyal amaç ve hedeflerin örtüştürülmesi, tüm paydaşların desteğiyle sağlam altyapılar oluşturulması, kurumsal sosyal sorumluluğun yaygınlaştırılması için teşvikler öngörülmesi, kurumsal sosyal sorumluluğun araç değil, amaç haline getirilmesi, tüm çalışanlar tarafından görevlerinin bir parçası olarak kabul edilmesinin sağlanması, bireysel bilinçten başlayarak örgütsel, toplumsal, ulusal, uluslararası ve nihayet küresel bilinç düzeylerinde yerleştirilmesi, sosyal denetim ve sosyal maliyet çalışmalarının takibi ve periyodik olarak raporlanması, tüm paydaşların erişimine olanak sağlanacak şekilde yayınlanması uygun olacaktır. Burada önemli olan husus, çalışmaların sürdürülebilir kılınmasıdır. 


\section{Kaynakça}

Aktan, C. C., İ. Y. Vural (2007) "Kurumsal Sosyal Sorumluluk (Uluslararası Kuruluşlar ve Hükümet-Dışı Organizasyonlar Tarafından Sürdürülen Başlıca Girişimler)", Çimento İşveren Dergisi, 3 (21): 4-21. (http://www.ceis.org.tr/dergiDocs/makale125.pdf), (E.T.: 02.03.2009).

Argüden, Y. (2002) Kurumsal Sosyal Sorumluluk, İstanbul: Rota Yayıncilık.

Aydede, C. (2007) Yükselen Trend Kurumsal Sosyal Sorumluluk, İstanbul: MediaCat Yayınları.

Birleşmiş Milletler (1999) Küresel İlkeler Sözleşmesi Tanıtım Broşürü, New York: Birleşmiş Milletler.

Boone, L. E., D. L. Kurtz (1999) Management (Fourth Edition), New York: McGraw Hill.

Bozkurt, Ö, T. Ergun, Sezen, S. (Ed.) (1998) Kamu Yönetimi Sözlüğü, Ankara: TODAİE.

Buhmann, K. (2006) “Corporate Social Responsibility: What Role For Law?”, Corporate Governance, 6 (2): 188-202.

Can, H. (1999) Yönetim ve Organizasyon, Ankara: Siyasal Kitabevi.

Carroll, A. B. (1979) “A Three-Dimensional Conceptual Model of Corporate Performance”, Management Review, 4: 497-505.

Carroll, A. B. (1991) "The Pyramid of Corporate Social Responsibility: Toward The Moral Management of Organizational Stakeholders”, Business Horizons, July/August: 39-48.

Carroll, A. B. (1999) "Corporate Social Responsibility: Evolution of A Definitional Construction”, Business and Society, 38 (8): 268-295.

Commission of The European Communities (2001) Green Paper - Promoting A European Framework For Corporate Social Responsibility, Brussels: Commission of The European Communities.

Davis, K., R. L. Blomstrom (1971) Business Society and Environment, Social Powerand Social Response (Second Edition), New York: McGraw-Hill Book Company.

Eren, E. (1990) İşletmelerde Stratejik Planlama ve Yönetim Cilt 1 (3. bs.), İstanbul: İstanbul Üniversitesi İşletme Fakültesi Yayınları.

Ergun, T. (2004) Kamu Yönetimi: Kuram, Siyasa, Uygulama, Ankara: TODAİE.

Ersöz, H. Y. (2007) Türkiye’de Kurumsal Sosyal Sorumluluk Anlayışının Gelişiminde Meslek ve Sivil Toplum Kuruluşları, İstanbul: İTO Yayınları, No: 2007-36.

European Commission (2011) A Renewed EU Strategy 2011-14 for Corporate Social Responsibility, Brussels: Commission of The European Communities.

Farmer, R. N., W. D. Hogue (1985), Corporate Social Responsibility, New York: Lexington Books.

Frederick, C. W., K. Davis, J. E. Post (1988) Business and Society: Corporate Strategy, Public Policy, Ethics (Sixth Edition), New York: McGraw-Hill Inc.

Freeman, R.E. (2010) Strategic Management: A Stakeholder Approach, New York: Cambridge University Press.

Grigsby, D. W., M. Stahl (1997) Strategic Management: Total Quality and Global Competition, New York: Blackwell Pub..

Hall, C. (ed.) (2013) United Nations Global Compact 2013 Annual Review, New York: United Nations.

Hawrysz, L., J. Foltys (2016) “Environmental Aspects of Social Responsibility of Public Sector Organizations”, Sustainability, 8 (1): 19.

Hirschland, M. J. (2006) Corporate Social Responsibility and The Shaping Global Public Policy, New York: MacMillan Company.

Idowu, S. O., N. Capaldi, L. Zu, A. Das Gupta (2013) Encyclopedia of Corporate Social Responsibility, Berlin: Springer. 
Ismail, M. (2009) "Corporate Social Responsibility and Its Role In Community Development: An International Perspective”, The Journal of International Social Research, 2 (9): 199-209.

KALDER (Türkiye Kalite Derneği) (2006) Kurumsal Sosyal Sorumluluk Kıyaslama Projesi Sonuç Raporu, İstanbul: KALDER.

Kotler, P., N. Lee (2008) Kurumsal Sosyal Sorumluluk (2.bs.), (Çev.Sibel Kaçamak), İstanbul: MediaCat Yayınları.

Lee, M., P. Dong (2008) "Review of the theories of corporate social responsibility: Its evolutionary path and the road ahead", International Journal of Management Reviews, 10 (1): 53-73.

Nemli, E. (2004) "Global Reporting Initiative ve Sürdürülebilir Raporlama Rehberi”, Önce Kalite Dergisi, Eylül, 12 (83): 35-37.

Leblebici, D. N. (2004) “Kamu Yönetimi: Dünyada ve Türkiye'deki Gelişimi” içinde M. K. Öktem ve U. Ömürgönülşen (ed.), Kamu Yönetimi - Gelişimi ve Güncel Sorunlar, Ankara: İmaj Kitabevi.

Özgen, E. (2006) Kurumsal Sosyal Sorumluluk Projeleri, İstanbul: Maviağaç Kültür Sanat Yayıncılık.

Özgener, Ş. (2004) İş Ahlâkının Temelleri: Yönetsel Bir Yaklaşım, Ankara: Nobel Yayınevi.

Özüpek, M. N. (2005) Kurum İmajı ve Sosyal Sorumluluk, Konya: Tablet Kitabevi.

Polatoğlu, A. (1993) Kamu Yönetimi, Genel İlkeler ve Türkiye Uygulaması, Ankara: ODTÜ. UNDP (BM Türkiye Koordinatörlüğü ve BM Kalkınma Programı Temsilciliği) (2008) Türkiye’de Kurumsal Sosyal Sorumluluk Değerlendirme Raporu, Ankara: UNDP Türkiye Temsilciliği.

Waters, R. D., H. K. Ott (2014) "Corporate Social Responsibility and the Nonprofit Sector: Assessing the Thoughts and Practices Across Three Nonprofit Subsectors", Public Relations Journal, 8 (3): 1-18.

Yamak, S. (2007) Kurumsal Sosyal Sorumluluk Kavramının Gelişimi, İstanbul: Beta Kitap.

\section{Elektronik Ortamdan Alıntılar}

SPK (2011) Kurumsal Yönetim İlkelerinin Belirlenmesine ve Uygulanmasına İlişkin Tebliğ, Seri IV, No: 56, (http://www.spk.gov.tr/displayfile.aspx?action=displayfile\&pageid=66\&fn $\quad=66 . p d f, \quad$ E.T.: 16.01.2012)

http://www.sucsr.com/kurumsal-sosyal-sorumluluk/makaleler/kssnedir.php, E.T.: 01.07.2009.

www.iso.org/iso/home/standards/iso26000.htm, çevrimiçi kaynak, E.T.: 10 Nisan 2014.

www.crinfo.worldbank.org/wbcrinfo/, çevrimiçi kaynak, E.T.: 12 Nisan 2014. 


\section{Ekler}

Ek.1. Yönetsel Süreçte Kurumsal Sosyal Sorumluluk Anketi

1. .............. ; okul öncesi eğitim kurumları (kreş ve ana sınıfı) açar.

2. .............. ; okul binalarının inşaatı ile bakım ve onarımlarını yapar.

3. ............. ; okulların her türlü araç, gereç ve malzeme ihtiyaçlarının karşılanmasına katkıda bulunur.

4. .............. ; sağlık hizmetlerinin desteklenmesi/ geliştirilmesi için çaba gösterir.

5. .............. ; sağlık hizmeti vermek üzere çeşitli tesisler açar.

6. ............. ; sosyal güvencesi olmayanlara veya ekonomik gücü yetersiz olanlara sağlık hizmeti sunar.

7. ............. ; sanatsal faaliyetleri destekler.

8. ............. ; sanatsal faaliyetler düzenler.

9. ............. ; sanatsal faaliyetler için zaman, mekân ve bütçe ayırır.

10. .............. ; sanatsal faaliyetlere yönelik sponsorluk faaliyetlerinde bulunur.

11.............. ; çevrenin korunmasına özen gösterir.

12. .............. ; kültür ve tabiat varlıkları ile tarihî dokunun korunmasına çalışır.

13. .............. ; kent tarihi bakımından önem taşıyan mekânların korunmasına özen gösterir, bakım ve onarımlarını yaptırır.

14............... ; kent tarihi bakımından önem taşıyan mekânların aslına uygun olarak yeniden inşa edilmesine çalışır.

15. .............. ; öğrencilere, amatör spor kulüplerine malzeme ve destek sağlar.

16. .............. ; ; amatör spor karşılaşmaları düzenler.

17. .............. ; yurt içi ve yurt dışı müsabakalarda üstün başarı gösteren veya derece alan sporculara ödül verir.

18. ............. ; son kullanım tarihinin yaklaşması, paketleme hatası, ihtiyaç fazlası gibi nedenlerle ziyan olma ihtimali bulunan malları ilgili firmalardan alarak ihtiyaç sahiplerine ulaştırır.

19. ............. ; sosyal adaletin sağlanması için çaba gösterir.

20. ............. ; ; iyi beslenemeyen vatandaşlara acil gıda yardımı sağlar.

21. .............. ; ; vatandaşlık haklarına yönelik bilinçlendirme faaliyetlerinde bulunur.

22. ............. ; tüketici haklarına yönelik bilinçlendirme faaliyetlerinde bulunur.

23. .............. ; çalışma standartlarına yönelik bilinçlendirme faaliyetlerinde bulunur

24.............. ; çalışanlarının sendikalaşma ve toplu müzakere özgürlüklerini destekler.

25. .............. ; zorla işçi çalıştırılmasına müsaade etmez.

26. .............. ; ; çocuk işçi çalıştırılmasına müsaade etmez.

27. .............. ; işe alım ve işe yerleştirmede ayrımcılık yapmaz.

28. ............. ; toplum gelişimine katkıda bulunmak üzere çeşitli sivil toplum kuruluşları / dernekleri ile işbirliği yapar.

29. .............. ; ; çalışanlarının gönüllü olarak katıldıkları faaliyetleri destekler.

30. .............. ; çalışanları kârlılık ve verimlilik amacı güdülmeyen, hizmet alanı dışındaki faaliyetlere katkı sağlarlar.

31. .............. ; devletin ulaşamadığ 1 ve hizmetlerin yetersiz alanlarda topluma yardımcı olmaya özen gösterir.

32. …….......in yürüttüğü bu tür faaliyetler, beklentilerimi ve ihtiyaçlarımı karşılıyor. 
33. ...............in ; kendi hizmet alanı dışındaki bir alanda kârlılık ve verimlilik amacı güdülmeyen bir etkinliği gerçekleştirmesini, kendisine tahsis edilen kaynakların kamu yararı gözetilerek, ancak farklı bir alanda kullanılmasını olumlu buluyorum.

34. Kârlılık ve verimlilik amacı güdülmeyen, ................in hizmet alanını dışındaki alanlarda icra ettiği gönüllülük faaliyetleri, özel sektörün yanı sıra kamu kesiminde de uygulanabilir.

35. Şirketlerin, kendilerinden beklenen hizmetlerin ötesinde sosyal sorumlulukları vardır.

36. ...............in ; kendi hizmet alanı dışındaki bir alanda kârlılık ve verimlilik amacı gütmeden icra ettiği faaliyetlerin kuruluşun imajına olumlu katkı sağladığını düşünüyorum.

37. ...............in ; kendi hizmet alanı dışındaki bir alanda kârlılık ve verimlilik amacı gütmeden icra ettiği faaliyetler, kuruluş ile vatandaş arasında bir güven ve huzur ortamı oluşturulmasına katkıda bulunmuştur. 